\title{
A IDEIA DE FENOMENOLOGIA EM HEIDEGGER E HUSSERL. \\ FENOMENOLOGIA HERMENÊUTICA DO AÍ-SER E FENOMENOLOGIA REFLEXIVA DA CONSCIÊNCIA*
}

\author{
Friedrich-Wilhelm von Herrmann \\ Universidade de Freiburg im Breisgau
}

\section{§1. A Fenomenologia hermenêutica em Ser e Tempo}

A fundação da Fenomenologia hermenêtutic no curso de 1919, conhecido por Kriegsnotsemester ${ }^{1}$, deu-se a partir de uma experiência originária metodológico-temática. Temática era a experiência originária da vida a-teorética e vivenciar, que encerrava ao mesmo tempo a experiência originária metódica segundo a qual o acesso ao domínio do a-teorético não pode estar dad• pela reflexão, mas apenas pela hermenêutica, que tem de ser desenvolvida antes de tudo o resto. A esta experiência originária metódico-temática corresponde a compreensão [Einsicht] fundamental de que a vida

*(C) Verlag Vittorio Klestermann, 2000. Tradução de Pedrø Sobral Pignatelli sob a coordenação científica de Irene Borges-Duarte, no âmbite do projecto de investigação "Heidegger em Português" (Pocti / P / FIL / 13034 /1998) do Centr de Filosofia da

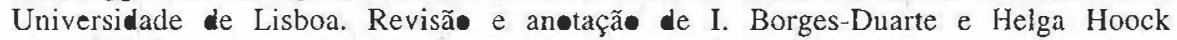
Quadrado, con assistência de Ana Falcato, que se ocupou da formatação do texto definitive. Agradece-se ao Autor, Prof. Friedrich-Wilhelm vøn Herrmann, e ao Editor Vittorio Klestermann a gentil cedência dos direitos de cópia para a presente versão de Der Begriff der Phänomen $\bullet$ gie bei Heidegger und Husserl ( $1^{a} \mathrm{ed} .1981$ ), realizada com base no texto publicado (em $3^{\mathrm{a}} \mathrm{ed}$.) com o títule de "Hermeneutische Phänomen Daseins und reflexive Phänomenologie des Bewußtseins", come capítulo III de Hermeneutik und Reflexion (Frankfurt, Klostermann, 2000).

Tanto as notas originais com• as que são introduzidas na presente tradução seguem a numeração, sendo as primeiras, contudo, antecedidads das iniciais N.T.

${ }^{1}$ N.T.: Die Idee der Philosøhie und das Weltanschaunngsproblem. Kriegsnotsemester 1919. [doravante KNS] Gesamtausgabe Bd. 56/57,Zur Bestimmung der Philosophie. Ed. de B. Heimbüchel. Frankfurt, Klostermann, 1987. 
a-teorética e, correlativamente, o mundo-da-vida [Lebenswelt] a-teorético não constituem um contexto de fundamentação, em que a experiência sensível e o mundo corpóreo experienciado de modo sensível seriam o fundante para todos os níveis mais elevados da vida da consciência. À experiência originária metódico-temática pertence, pois, a compreensão encaminhadora de que a ideia de um tal contexto de fundamentação não se extraiu fenomenologicamente da vida a-teorética, mas brota do acesso teorético-reflexivo à vida enquanto vida da consciência.

Ambas, a experiência originária metódico-temática e a correspondente compreensão, constituem o característico da hermenêutica fundada por Heidegger. Todos os primeiros cursos de Friburgo e Marburgo que se seguem a $K N S$ permanecem determinados, quanto ao método e à temática, pela experiência hermenêutica originária. Por isso, todos os desenvolvimentos metódicos nestes textos lectivos têm sempre de ser lidos dentro do horizonte da experiência hermenêutica originária. O caminho da fenomenologia hermenêutica da vida a-teorética e fáctica, iniciado em $K N S$, desemboca na fenomenologia hermenêutica do aí-ser [Dasein], sistematicamente elaborada em Ser e Tempo. No $\S 7$ da introdução - parágrafo acerca do método desta obra - Heidegger desenvolve o seu conceito preliminar [Vorbegriff] da Fenomenologia hermenêutica do aí-ser. Na medida em que a hermenêtica do aí-ser é fenomenologia, ela parte da ideia metódica da fenomenologia fundada por Husserl, que se enuncia no princípio de todos os princípios e na máxima de investigação «voltar às coisas mesmas». Mas na medida em que a fenomenologia do aí-ser é hermenêutica, demarca-se da fenomenologia de Husserl, que se move dentro dos actos de reflexão. Apenas se pode compreender o parágrafo metodológico de Ser e Tempo nas suas intenções mais profundas a partir duma ligação e dum confronto com a fenomenologia reflexiva de Husserl. Sem um conhecimento profundo da fenomenologia husserliana, no que toca ao seu método e conteúdo, a leitura do parágrafo metodológico permanece obtusa. A ligação à máxima de investigação fenomenológica e o confronto com o traço fundamental da fenomenologia husserliana formam o plano de fundo diante do qual Heidegger desenvolve o conceito preliminar de Fenomenologia hermenêutica. É certo que Husserl só é expressamente mencionado quase no fim do parágrafo, mas a maneira como é mencionado desperta a atenção do leitor, pois nela se declara que a fenomenologia hermenêutica do aí-ser apenas se tornou possível a partir dum encontro com a fenomenologia reflexiva da consciência. Por isso, vamos examinar os desenvolvimentos do parágrafo metodológico tendo em vista a Fenomenologia husserliana, a fim de reconhecer onde Heidegger adere a esta e onde se demarca dela. Isso conduz, contudo, a que também apresentemos nos seus traços fundamentais o conceito husserliano da Fenomenologia reflexiva da consciência. 
A exposição do conceito preliminar de Fenomenologia hermenêutica no parágrafo metodológico de Ser e Tempo tem de peculiar que o método fenomenológico-hermenêutico é nele apresentado segundo dois princípios: o do seu modo de proceder e o do seu método de acesso. No que respeita ao primeiro - o modo de proceder - é adoptada a máxima de investigação fenomenológica instituída por Husserl do «voltar às coisas mesmas». O segundo princípio - o método de acesso - formula as indicações do caminho para o acesso metódico ao campo de investigação hermenêutico. $O$ método de acesso fenomenológico-hermenêutico consiste na unidade triádica indicativa do ponto de partida, do acesso e do trajecto, que na reelaboração da Terceira secção da primeira parte de Ser e Tempo, «Tempo e Ser», vêm a ser esclarecidos enquanto redução, construção e de-struição hermenêuticas ${ }^{2}$. Também o método fenomenológico-reflexivo de Husserl se articula em conformidade com dois princípios, designando o primeiro, igualmente, a máxima de investigação fenomenológica - portanto, o modo de proceder fenomenológico -, enquanto que o segundo constitui também um método de acesso, a epoché e a redução fenomenológico-reflexivas. Em consequência disto, no segundo e no terceiro parágrafos, analisaremos estes dois princípios metódicos, por um lado, na Fenomenologia hermenêutica e, por outro, na Fenomenologia reflexiva e confrontá-los-emos um com o outro. No parágrafo final, e tomando como base o parágrafo metodológico, centrar-nos-emos na determinação fundamental da hermenêutica, cujo próposito apenas pode ser entendido se a compreendermos na sua demarcação relativamente à reflexão fenomenológica. Se o lógos da fenomenologia for hermenêutico, então o modo de proceder fenomenológico e o correspondente método de acesso serão de natureza hermenêutica. Se, pelo contrário, o lógos da fenomenologia se define como reflexivo, então o modo de proceder e o método de acesso fenomenológicos terão um carácter reflexivo.

Além disso, nesta comparação entre os conceitos hermenêutico e reflexivo de Fenomenologia importa-nos mostrar dois caminhos da Fenomenologia que, mesmo quando se excluem um ao outro com toda a acuidade, comportam sempre uma verdade própria.

2 N.T.: Veja-se Die Grundprobleme der Phänomenologie. Sommersemester 1927. Gesamtausgabe Bd. 24. Ed. de F.-W. von Herrmann. Frankfurt, Klostermann, 1975. Leia-se a este propósito: von Herrmann, F.-W., Heideggers 'Grundprobleme der Phänomenologie'. Zur 'Zweiten Hälfte' von 'Sein und Zeit'. Frankfurt, Klostermann, 1991. Trad. Cast. de I. Borges-Duarte: La 'Segunda Mitad' de 'Ser y Tiempo'. Madrid, Trotta, 1997. 


\section{$\S 2$. A Fenomenologia enquanto modo de proceder (primeiro princípio metódico)}

\section{A) O conceito formal de Fenomenologia em Husserl e em Heidegger}

No começo do parágrafo metodológico ${ }^{3}$, Heidegger sublinha que a fenomenologia é primariamente um conceito metodológico, que designa não o objecto temático da Filosofia, mas o como da sua investigação, o modo de proceder. Tendemos com demasiada facilidade a equiparar o termo «fenomenologia», no contexto da obra husserliana, com a análise intencional das vivências de consciência e, no contexto da obra heideggeriana, com a análise existenciária do aí-ser. Em tal equiparação atendemos insuficientemente ao facto de a fenomenologia não visar primariamente o objecto temático, o «quid temático [Sachhaltiger Was] dos objectos da investigação filosófica»", mas apenas o seu modo de investigação. A Fenomenologia não é uma disciplina filosófica ao lado da Ontologia, Epistemologia ou Ética, porque enquanto método não tem nenhum campo de especialidade a acrescentar aos da Ontologia, Epistemologia ou Ética. Cada uma destas disciplinas podia caracterizar-se como fenomenologia, a saber, no caso de ela querer compreender-se fenomenologicamente, do ponto de vista metodológico. $\mathrm{O}$ autenticamente fenomenológico da fenomenologia da consciência não é a constituição [Verfasstheit] intencional dos actos de consciência, mas o método específico com cuja ajuda a reflexão filosófica descobre a constituição intencional da consciência. E do mesmo modo, o que a fenomenologia do aí-ser tem de autenticamente fenomenológico não são as estruturas-existenciárias que formam o ser (Existência) do aí-ser, enquanto um todo estrutural, mas é também aqui o método, que conduziu ao pôr a descoberto [Freilegung] analítico das estruturas do ser do homem.

O objecto temático de Ser e Tempo - o ser do ente e o sentido do ser em geral - deve ser tratado fenomenologicamente. Visto que fenomenologia é primariamente um conceito metodológico, este tratado não estabelece nem um «ponto de vista» nem uma «corrente», já que a fenomenologia não é nem pode nunca chegar a ser nem uma coisa nem outra, enquanto se compreende a si mesma». A ênfase heideggeriana na independência do ponto de vista e na autonomia face a qualquer corrente, próprias da fenomenologia, é uma daquelas formulações expressas de forma intencionadamente ambígua. As palavras «ponto de vista» e «corrente» estão entre aspas, porque com elas Heidegger se reporta a Husserl. Elas pertencem ao contexto em que Husserl enuncia a sua própria compreensão [Selbstverständnis] do método fenome-

${ }^{3}$ M. Heidegger, Sein lınd Zeit, Tübingen, Niemeyer, 1979, p. 27 (Gesamtausgabe Bd. 2, p. 37). [N.T.: Doravante citar-se-á, respectivamente, a obra e a edição, pelas siglas $S u Z$ e $G A$.]

${ }^{4}$ Ibidem.

${ }^{5}$ Ibidem 
nológico. O primeiro tom em que a recusa heideggeriana de qualquer ponto de vista ou corrente se pretende fazer ouvir é o da sua ligação positiva com a inteligência husserliana do seu próprio método fenomenológico. $\mathrm{Na}$ introdução ao $2^{\circ}$ volume das Investigações Lógicas, Husserl formula uma tal autonomia face a qualquer corrente ou ponto de vista, própria do método fenomenológico, como o princípio da ausência de pressupostos ${ }^{6}$. No livro primeiro das Ideias para uma Fenomenologia e uma Filosofia fenomenológica, Husserl descreve do seguinte modo a atitude fundamental característica da Fenomenologia: tomamos o «nosso ponto de partida daquilo que antecede todos os pontos de vista: o âmbito global do que se dá de por si de modo intuitivo e ainda prévio a todo o pensar teorético, tudo aquilo que se pode ver e apreender de forma imediata» ${ }^{7}$, e, poucas páginas antes ${ }^{8}$, fala das «correntes filosóficas fácticas», das quais não faz uso a filosofia que trabalha fenomenologicamente.

$\mathrm{O}$ que Husserl entende por independência do ponto de vista e autonomia face a qualquer corrente, próprias da filosofia que procede de modo fenomenológico, pode ser condensado da seguinte maneira: a filosofia fenomenológica pretende fundar-se, enquanto filosofia científica, abstraindo expressamente dos pontos de vista e das correntes previamente existentes; no ponto de partida e na sua materialização enquanto ciência que se torna filosófica não quer fazer uso dos pontos de vista e correntes previamente existentes; neste sentido, ela quer obter os seus conhecimentos filosóficos na ausência de pressupostos, obtê[-los] somente no ter em vista [Schauen] reflexivo-espiritual aquilo que é dado intuitivamente ao olhar [Blick] que tem reflexivamente em vista, aquilo que pode ser apreendido e visto espiritualmente como dado de modo intuitivo.

Ora, se Heidegger afirma que o tratado Ser e Tempo não prescreve nenhum ponto de vista ou corrente, desde que o seu objecto temático seja tratado de modo fenomenológico, então ele identifica-se em primeiro lugar com a caracterização husserliana da fenomenologia. Tanto para Heidegger como para Husserl, a fenomenologia, no respeitante ao conteúdo, não constitui um ponto de vista perfilado nem uma corrente determinada, mas sim um conceito de método. Enquanto tal, a fenomenologia visa igualmente, segundo Husserl, não o objecto temático da filosofia, mas o como do seu proceder.

A ênfase dada por Heidegger à autonomia face a qualquer ponto de vista ou corrente deve, contudo, ser ouvida num segundo tom em que se expressa a

${ }^{6} \mathrm{E}$. Husserl, Logische Untersuchungen [doravante $L U$ ], Bd. II, I Teil (I-V Logische Untersuchung). Halle, Niemeyer, 3. unveränderte Auflage 1922, § 7, p. 19. Também em Husserliana Bd. XIX/1. Ed. de U. Panzer. Den Haag, Nijhoff, 1984, p. 24.

${ }^{7}$ E. Husserl, Ideen zu einer reinen Phänomenologie und phänomenologischen Philosophie. Erstes Buch: Allgemeine Einführung in die reine Phänomenologie. Tübingen, Niemeyer, 1995 (5. Auflage). § 20, p. 38. Também em Husserliana Bd. III, Ed. de W. Biemel. Den Haag, Nijhoff, 1950, 46.

${ }^{8}$ Ibidem, $§ 18,33$ (Husserliana Bd. III, 41). 
autonomia metódica e temática face a Husserl. Neste segundo tom, Heidegger pretende comunicar ao leitor que o tratado Ser e Tempo, ao proceder fenomenologicamente, não prescreve nem metodológica nem tematicamente a Fenomenologia de Husserl. Todavia, este segundo tom não revoga o primeiro. Ele não se coloca em oposição ao primeiro, mas constitui a sua precisão. No segundo tom, Heidegger toma Husserl à letra: se a fenomenologia como conceito metodológico é independente, quanto ao conteúdo, de pontos de vista e correntes filosóficas, também tem de ser independente do cunho específico que Husserl imprimiu ao método fenomenológico, e do domínio temático que Husserl determinou como o objecto da filosofia fenomenológica. Sem dúvida, Husserl praticou, em ampla medida e desvinculado de qualquer ponto de vista ou corrente, o método fenomenológico do apreender que tem reflexivamente em vista [reflexiv schauendes Erfassen] aquilo que é trazido ao estar-dado de forma intuitiva. Todavia, o que tematizou como o campo de investigação da filosofia fenomenológica e reconheceu com a ajuda do método fenomenológico foi a vida egóica da consciência com as suas vivências constituídas intencionalmente, o que pareceu constituir, daí para a frente, o óbvio e único objecto da filosofia fenomenológica. Em virtude disso, a Fenomenologia tornou-se ela própria, mais tarde, num ponto de vista fixo em termos de metodologia e temática. A fenomenologia como método passou a ser simultaneamente uma filosofia com contornos bem delimitados no que respeita à temática: em primeiro lugar, converteu-se numa fenomenologia das vivências puras da consciência, depois numa fenomenologia da vida transcendental da consciência ou da subjectividade transcendental. Se, em Ser e Tempo, Heidegger se refere ao método fenomenológico desenvolvido pela primeira vez por Husserl (primeiro tom), ele tem simultaneamente de dar a entender ao leitor que isso não o leva a dedicar-se ao ponto de vista fenomenológico concreto de Husserl, nem a nenhuma outra corrente fenomenológica existente previamente - por exemplo a de Max Scheler - (segundo tom). Tal como Husserl, em nome da fenomenologia como método, reclama para o seu investigar fenomenológico independência dos pontos de vista e corrente tradicionais, também Heidegger, em nome da mesma metodologia, reivindica independência do panorama da fenomenologia até aí existente. Neste sentido, diz Heidegger perto do final do parágrafo metodológico: o essencial da Fenomenologia não reside em «ser efectivamente real enquanto corrente filosófica. Acima da realidade encontra-se a possibilidade. A compreensão [Verständnis] da Fenomenologia reside unicamente no captar-se a si própria enquanto possibilidade» ${ }^{9}$. Tal como Husserl aplicou o método fenomenológico com independência metódica relativamente a pontos de vista e correntes existentes, assim também Heidegger pretendeu executar o ver fenomenológico desvinculado das correntes fenomenológicas até aí existentes. 
A caracterização da Fenomenologia enquanto conceito metodológico, mediante a referência à autonomia face a qualquer ponto de vista ou corrente constitui, contudo, apenas uma circunscrição negativa, que, enquanto tal, requer uma caracterização positiva do método fenomenológico. Sem dúvida, esta ecoa de algum modo na delimitação negativa, mas só entra em acção de forma irrestrita quando se formula a Fenomenologia na sua máxima de investigação: «às coisas mesmas». Heidegger põe esta máxima entre aspas ${ }^{10}$, porque com ela também faz referência a Husserl. Na introdução citada do II volume das Investigações Lógicas, diz-se: «Queremos voltar "às coisas mêsmas". Em intuições plenamente desenvolvidas pretendemos colocar-nos perante a evidência de que este dado aqui em abstração executada de forma actual é veraz e efectivamente aquilo que os significados das palavras visam na expressão legal [visadas são aqui as leis ideais da lógica pura]» ${ }^{11}$. E nas Ideias I, diz Husserl: «Julgar racional ou cientificamente as coisas significa, porém, orientar-se pelas coisas mesmas, retornar dos discursos e opiniões às coisas mesmas, inquiri-las nas sua auto-doação [Selbstgegebenheit] e pôr de lado todos os preconceitos estranhos à matéria em questão» ${ }^{12}$.

$\mathrm{Na}$ citação referente às Investigações Lógicas, além da expressão «voltar às coisas mesmas», também surgiu o termo evidência. Ambos estão interligados. No olhar que tem reflexivamente em vista uma coisa [Sache] (o respectivo objecto temático do filosofar), trazer esta coisa, tal como ela é em si mesma, ao estar-dado intuitivo não significa senão trazê-la à evidência no ter em vista reflexivo. Não devemos traduzir «evidência» em Husserl apenas por «certeza». Husserl utiliza este termo no seu significado literal de ver para fora [Heraussehen] e visão penetrante [Einsicht] no sentido do ter em vista reflexivo e daquilo que nele é visto. Nas Ideias I, Husserl também caracteriza o método fenomenológico, que se põe ao abrigo da máxima «às coisas mesmas", como o princípio de todos os princípios ${ }^{13}$ e nas Meditações cartesianas como o princípio da evidência e determina-o como o primeiro princípio metódico ${ }^{14}$, que, enquanto primeiro, permite esperar pelo menos um segundo.

Este primeiro princípio do método fenomenológico significa para Husserl que, no caminho do meu investigar filosofante, «não posso pronunciar ou fazer vigorar nenhum juízo que não haja tomado da evidência, das experiências em que as respectivas coisas e estados de coisas existem presentemente para mim enquanto elas mesmas» ${ }^{15}$. Husserl concebe a evidência

\footnotetext{
${ }^{10}$ Ibidem, 27 (GA 2, 37).

${ }^{11}$ E. Husserl, LU, Bd. II, I. Teil, § 2, 6 (Husserliana XIX/1., 10)

${ }^{12}$ E. Husserl, Ideen I, § 19, 35 (Husserliana III, § 19, 42)

${ }_{13}^{13}$ Ibidem, § 24, 43 (Husserliana III, § 24, 52)

${ }^{14}$ E. Husserl, Cartesianische Meditationen und Pariser Vorträge. Husserliana I. Ed. de v. S. Strasser. Den Haag, Nijhoff, § 5, 54.

${ }^{15}$ Ibidem.
} 
como um aperceber-se-espiritual-da-coisa-mesma [Die-Sache-selbst-geistig-zu-Gesicht-bekommen $]^{16}$.

Se Heidegger, na sua discussão do método fenomenológico, realça a autonomia face a qualquer ponto de vista ou corrente e faz referência à máxima «às coisas mesmas», na verdade ele parte apenas do que é, para Husserl, o primeiro princípio metódico, do princípio da evidência entendida ainda de modo formal, que Husserl concebe como um ter-à-vista-a-coisa-ela-mesma e que nesta versão formal ainda não foi concretizada relativamente à diferença entre a evidência adequada e a evidência apodíctica. Além disso, Heidegger retoma este princípio metódico do voltar às coisas mesmas apenas na dimensão formal do puro conceito metodológico, sem a implicação temática husserliana.

Acontece, todavia, que também nạo aceita este conceito metodológico formal na versão e formulação que Husserl lhe deu. Ao invés, elabora um conceito formal próprio da fenomenologia, que apenas coincide com o princípio formal husserliano da evidência no apecto fundamental-formal.

Contudo, no parágrafo metodológico não apenas se procura o conceito formal de fenomenologia, mas sobretudo o conceito fenomenológico de Fenomenologia ${ }^{17}$. Heidegger entende por este o conceito de fenomenologia filosófico concreto, que é concreto porque está desformalizado relativamente àquilo que deve ser o objecto temático da filosofia que procede fenomenologicamente. Além deste [conceito] fenomenológico ele ainda fala do vulgar, pelo qual entende o conceito de Fenomenologia científico-positivo. Também este é um conceito concreto de Fenomenologia, na medida em que nele o conceito formal de fenomenologia se desformalizou em relação àquilo que, numa ciência positiva, constitui o objecto da investigação que se compreende como fenomenológica. Veremos que o comum da compreensão da Fenomenologia em Heidegger e Husserl se encerra naquilo que Heidegger apresenta como conceito formal de Fenomenologia. A sua diferença surge ao tratar-se da questão de como é desformalizado esse conceito formal de Fenomenologia, por um lado em Heidegger e por outro em Husserl.

O caminho que Heidegger segue para a obtenção do seu conceito formal de Fenomenologia parte de uma clarificação do significado dos dois componentes da palavra «fenomeno-logia» ${ }^{18}$ Heidegger traduz fenómeno do grego phainómenon, por o que-se-mostra-a-respeito-de-si-mesmo [das Sich-an-ihm-selbst-zeigende] e, neste sentido, o manifesto. Ele não diz apenas, de modo lexical, o que-se-mostra, mas o que-se-mostra-a-respeito-de-si-mesmo, de modo a tornar claro que aquilo que se mostra, a coisa que se mostra, mostra-se tal como ela mesma é, ou mais precisamente, como ela é a

\footnotetext{
${ }^{16}$ Ibidem, 52.

${ }^{17}$ M. Heidegger, SuZ 31 (GA 2, 42).

${ }^{18}$ Ibidem, 28 (GA 2, 38).
} 
respeito a si mesma [an-ihr-selbst]. Neste ponto fica decidido que: aquilo enquanto o qual a coisa se mostra, é tal qual a coisa é na verdade.

Heidegger esclarece este conceito formal de fenómeno mediante uma dupla demarcação: por um lado, relativamente à variante de privação, na figura da aparência $[\text { Schein }]^{19}$, por outro, em relação ao que ele designa por aparição [Erscheinung $]^{20}$. O que se mostra tal como é a respeito a si mesmo também se encontra na possibilidade de se mostrar tal como não é a respeito a si mesmo. Em tal caso, afirmamos que a coisa apenas tem aspecto de [ser] de uma certa maneira, mas, na verdade, não é. Contudo, para que algo possa aparecer desse modo tem mesmo que poder mostrar-se. Embora a palavra grega phainómenon compreenda lexicalmente ambos os significados de o que-se-mostra-a-respeito-de-si-mesmo e de o aparente, Heidegger com a palavra «fenómeno» caracteriza terminologicamente tão somente o modo positivo do mostrar-se, tomando o segundo significado, de modo negativo enquanto privativo, como aparência.

Com todo o rigor, Heidegger diferencia do fenómeno, enquanto o que-se-mostra-a-respeito-de-si-mesmo, e da aparência, enquanto o que-não-se-mostra-a-respeito-de-si-mesmo, aquilo que ele designa terminologicamente como aparição. Enquanto a aparência constitui uma modificação privativa do mostrar-se, a aparição não é de todo algo que se mostre, nem o aparecer é um mostrar-se, mas apenas um «dar notícia de si» [Sichmelden]. Para exemplificar o que entende por aparição, em contraste com algo que se mostra, Heidegger menciona aquilo que endendemos ser a aparição sintomática de uma doença, algo assim como o rubor facial, que indica a existência de febre, que, por sua vez, é indício de uma perturbação do organismo. No rubor das faces, a doença não se mostra a si mesma, apenas dando notícia de si, justamente, por intermédio do rubor facial, que, por seu lado, se mostra. Na medida em que se mostra, ele dá notícia, no seu mostrar-se, da doença, que dá notícia de si e [também] se mostra, embora não da mesma maneira que o faz o rubor facial. A profunda diferença entre o fenómeno, enquanto o-que-se-mostra-a-respeito-de-si-mesmo, e a aparição, enquanto o-que-dá-notícia-de-si, e que não apenas não constitui um modo privativo do mostrar-se (o que seria o caso da aparência), como também não é de todo nenhum mostrar-se, é ilustrada por Heidegger pelo facto dele tomar o fenómeno como uma maneira excepcional do encontrar-se com [Begegnisart] algo, ao passo que a aparição não é uma maneira de se encontrar com, mas sim uma referência de remissão que está a ser no ente [ein seiender Verweisungsbezug im Seienden $]^{21}$. 
Se o que seja o dado - no modo excepcional de se encontrar com que é próprio do fenómeno, do mostrar-se-a-respeito-de-si-mesmo - permanecer indeterminado, é que se trata do conceito formal de fenómeno ${ }^{22}$.

À determinação do conceito formal de Fenomenologia pertence igualmente a caracterização daquilo que significa o lógos na fenomenologia. Como significado fundamental de lógos Heidegger refere o discurso [Rede], e como carácter essencial do discurso indica o tornar-manifesto algo, o fazer ver mostrativo ${ }^{23}$.

Se fenómeno significa o-que-se-mostra-a-respeito-de-si-mesmo e lógos o fazer ver mostrativo, então fenomenologia significa um fazer ver mostrativo de o-que-se-mostra-a-respeito-de-si-mesmo. Ou, como Heidegger diz: «Isso que se mostra tal como se mostra a partir de si próprio, tal como se faz ver a partir de si próprio» ${ }^{24}$. Esta é a versão heideggeriana do conceito formal de fenomenologia, do qual ele diz que contém em si expressa a máxima de investigação fenomenológica «às coisas mesmas». O conceito formal de fenomenologia tomado deste modo quer dizer: só dar como um estado de coisas verdadeiramente conhecido, aquilo que é levado ao mostrar-se-a-respeito-de-si-mesmo num ter à vista pensante. Seja qual for o objecto temático tratado, ele deve, para um tratamento científico, ser encontrado e apresentar-se, em qualquer caso, no modo do mostrar-se-a-respeito-de-si-mesmo, a fim de que o tratamento científico, partindo do seu próprio objecto, i.e, sem o falsificar, possa fazer vê-lo tal como este se mostra a partir de si mesmo. Fenómeno não significa o objecto temático ele mesmo, mas apenas a maneira como vem ao encontro da investigação e como se lhe apresenta. O lógos da fenomenologia diz como deve ser investigado o objecto temático que vem ao nosso encontro no modo do mostrar-se-a-respeito-de-si-mesmo. Tal como Heidegger sublinha, o lógos da fenomenologia é o fazer-ver-a-partir-da-coisa-mesma [Von-ihm-selbst-her-Sehenlassen] que acontece imediatamente no que-se-mostra-a-respeito-de-si-mesmo, enquanto pôr à mostra [Aufweisung] directo e directa identificação [Ausweisung], i.e., enquanto pôr à mostra e identificação ${ }^{25}$. «Pôr à mostra» e «identificação» também em Husserl são conceitos metódicos, pertencentes à esfera do primeiro princípio metódico da evidência formal, do qual sabemos, entretanto, que é coincidente na sua amplitude formal com o conceito de Fenomenologia apresentado por Heidegger. 
B) A desformalização do conceito formal de Fenomenologia no conceito vulgar de Fenomenologia (científico-positivo)

Retomemos o olhar prévio sobre o problema da desformalização do conceito formal de Fenomenologia dado em passagens anteriores das nossas reflexões. A desformalização constitui o problema da relação do método com o seu objecto, sem que isso comporte voltar atrás no que respeita à separação entre método e objecto temático. A desformalização é, enquanto concretização, o problema da determinação do objecto temático quanto ao seu conteúdo, objecto este que deve ser apreendido e posto à mostra cientificamente no tipo de ir ao encontro próprio do mostrar-se-a-respeito-de-si-mesmo.

Para Heidegger, uma tal desformalização pode fundamentalmente efectuar-se em duas direcções. A diferenciação entre estas duas direcções de concretização do conceito formal de Fenomenologia determina-se a partir da ideia fundamental da sua filosofia temática: a partir da diferença ontológica entre ser e ente. Visto que na questão da desformalização se trata da questão do objecto temático, no modo do mostrar-se-a-respeito-de-si-mesmo, a desformalização diz respeito sobretudo ao conceito formal de fenómeno, sem esquecer que fenómeno constitui o modo de encontrar e do apresentar-se do objecto temático.

Uma destas direcções é a que se orienta para o ente. O ente - isto é a totalidade daquilo que são as coisas em sentido lato, o ente não humano. Ao ente pertencem as coisas inanimadas da natureza, os seres vivos não humanos, os utensílios produzidos pelo homem, e também as obras de arte criadas por ele. Mas ao ente pertence igualmente ainda o homem assim como todas as formas comunitárias desenvolvidas por ele e as suas instituições. Ora, se isto que é trazido ao estar-dado no modo do mostrar-se-a-respeito-de-si-mesmo constitui o ente de um qualquer domínio, então desformalizou-se o conceito formal de fenómeno no seu conceito vulgar. O conceito vulgar de fenómeno, enquanto habitual, remete para um conceito não habitual de fenómeno.

Importa ainda reter que com o conceito vulgar de fenómeno não se está a pensar no ente tal como ele se mostra no acesso pré-científico a ele, mas no ente enquanto constitui o objecto temático da investigação científica e, na verdade, na investigação científico-positiva. Isto torna-se claro quando Heidegger diz que «qualquer pôr à mostra do ente, tal como ele se mostra-a-respeito-de-si-mesmo», pode ser chamada "fenomenologia» ${ }^{26}$. Qualquer pôr à mostra do ente - com isso não se está a pensar no acesso natural, pré- e extra-científico, ao ente, mas somente no acesso científico-positivo ao ente, característico de um domínio de investigação científico. Fenomenologia é, pois, em qualquer caso, e, portanto, também enquanto fenomenologia vulgar, 
um método, que é essencialmente de natureza científica e nunca o modo de acesso natural. É necessário que distingamos os modos de acesso extra-científico-naturais dos modos de acesso científicos àquilo que é.

Uma questão própria da filosofia é, naturalmente, saber como é que os modos de acesso pré-científicos terão de ser compreendidos numa meditação filosófica sobre eles. Em consonância com a sua abordagem da consciência, Husserl toma os modos de acesso pré- e extra-científicos como aquilo a que, duma forma global, ele chama a mera experiência sensível (ou experiência do mundo da vida): a percepção referida ao presente e as suas modificações-presentificadoras da lembrança do presente, referida ao presente, da relembrança referida ao passado e da pré-lembrança (expectativa) referida ao futuro. Em contraposição a isto, Heidegger, com base na sua abordagem do aí-ser, estabelece como modos de acesso pré-científicos aquilo que terminologicamente qualifica de modos de relacionamento [Verhaltungen] do estar ocupado que vê em torno [umsichtiges Besorgen] do trato [Umgang] ocupado com o ente, junto do qual, em cada caso, residimos.

No quotidiano pré-científico não se precisa de nenhum método, nenhum pôr à mostra metódico, para trazer ao mostrar-se, antes de mais nada, as coisas da nossa praxis vital quotidiana e natural. Pelo contrário, uma investigação científico-positiva do tipo das ciências naturais ou das ciências do espírito requer sempre um método. Pois ela não pretende apreender isso que nos está sempre dado e que desde sempre vem ao nosso encontro sem método, mas gostaria de investigar um domínio do ente em relação àqueles aspectos em que esse [domínio] certamente já não se mostra ao modo de acesso natural. $\mathrm{O}$ conceito vulgar de fenómeno e de fenomenologia indica que cada investigação positivo-científica pode caracterizar-se metodicamente como fenomenológica, designadamente no caso em que esta, na observância dos seus métodos de investigação específicos relativos a um domínio e fundados nesse domínio, se coloca sob a máxima geral, de apreender aquilo que pretende conhecer pela via do pôr à mostra e da identificação.

C) A desformalização do conceito formal de Fenomenologia num conceito fenomenológico (filosófico).

Esta era uma das duas direcções em que poderia dar-se a desformalização do conceito formal de fenómeno e de Fenomenologia. Aquilo de que nela se tratava era do método fenomenológico das ciências positivas e não ainda, por conseguinte, do método fenomenológico da filosofia. Mas é mesmo só da determinação da fenomenologia enquanto método da filosofia, porém, que trata o parágrafo metodológico de Ser e Tempo. O objecto temático da filosofia constitui para Heidegger o ser do ente, e isso de tal modo que a questão do ser do ente é conduzida pela do sentido do ser em geral. Ora, se o conceito formal de fenómeno for desformalizado na direcção do 
ser do ente e do seu sentido, obteremos o conceito filosófico propriamente dito e, portanto, fenomenológico de fenómeno e de Fenomenologia.

a) A desformalização heideggeriana do conceito formal de fenómeno na direcção do ser do ente: a Abertura ex-stático-horizontal e com carácter de mesmidade do ser.

Heidegger vai responder que a desformalização do conceito formal de fenómeno no conceito filosófico-fenomenológico tem que ir na direcção do ser do ente, para o que entrelaça questões ${ }^{27}$. Através delas, numa pre-visão inexplícita do carácter de coisa [Sachheit] do ser do ente, deverá transparecer em que medida é que o fenómeno, que tem de ser posto à mostra e identificado, é - em sentido restrito, ou seja, fenomenológico - o ser e não o ente.

Na primeira questão pergunta-se acerca do modo como tem de ser desformalizado o conceito formal de fenómeno, o que-se-mostra-a-respeito-de-si-mesmo, no conceito fenomenológico, e de que maneira o conceito fenomenológico se diferencia do conceito vulgar. A segunda questão pergunta que tipo de objecto é esse que a fenomenologia, enquanto método da filosofia, da filosofia fenomenológica, deve fazer ver. No fazer ver encontra-se implicado o facto de ser através dele que a coisa [Sache] é, antes de mais nada, posta à mostra e levada ao mostrar-se-a-respeito-de-si-mesmo. Contudo, isso aplica-se igualmente - como vimos - àquilo que a ciência positiva põe, em cada caso, à mostra, em matéria do que é objecto da sua investigação. O que a fenomenologia, enquanto método da filosofia, deve fazer ver tem, portanto, de ser algo que não se mostra no vir ao encontro natural e pré-científico, próprio do ente, mas tão-pouco na tematização científica do ente - algo que só a filosofia e nunca a ciência pode fazer ver ou pôr à mostra. Por isso, a terceira questão procura o que tem de ser chamado fenómeno num sentido «extraordinário» e não vulgar. Com isto está já dito, em forma de pergunta, que o extraordinário que-se-mostra-a-respeito-de-si-mesmo não é nem o ente natural, nem o ente que se mostra de modo científico-positivo. A quarta questão agudiza a terceira: «O que é que, de acordo com a sua essência, é necessariamente tema de um explícito pôr à mostra?» ${ }^{28}$ Que coisa constitui, em virtude do seu carácter de coisa [Sachheit], necessariamente o objecto temático de um pôr à mostra explícito? «Explícito» está escrito em itálico, porque aquilo de que aqui se trata é de um tipo extraordinário de pôr à mostra de modo explícito frente àquele que está em jogo nas ciências positivas. Evidentemente, o motivo pelo que a fenomenologia deve fazer ver de forma mostrativa isso que não se mostra, nem no acesso natural ao ente nem no acesso científico-positivo, carece de um explícito pôr à mostra. Estas qua- 
tro questões pretendem em conjunto abrir progressivamente o olhar para uma coisa que, por não se mostrar nem no acesso natural ao ente nem no acesso científico-positivo, exige necessariamente a partir de si mesma o método fenomenológico, enquanto um explícito pôr à mostra, como único tipo adequado de tratamento da sua investigação temática.

A terceira e quarta questões prepararam a resposta, pelo que esta já só precisa de ser enunciada. A resposta dá-se de tal modo que Heidegger, antes de denominar aquilo que a Fenomenologia deve fazer ver, o caracteriza de um modo formal e, mais precisamente, na sua relação com o-que-se-mostra nos acessos natural e científico-positivo. A resposta decisiva reza assim: trata-se, «de forma manifesta, daquilo que, justamente, à partida e na maior parte das vezes, não se mostra, daquilo que está encoberto, relativamente ao que, à partida e na maior parte das vezes, se mostra, mas que, ao mesmo tempo, é algo; daquilo que corresponde essencialmente ao que, à partida e quase sempre, se mostra, e de tal maneira que constitui o seu sentido e fundamento» ${ }^{29}$. A coisa que, por força do seu carácter de coisa, carece, em sentido eminente, de um pôr à mostra explícito para se tornar fenómeno, algo que-se-mostra-a-respeito-de-si-mesmo, é uma coisa tal que, «justamente, à partida e quase sempre, se não mostra» - nem no mostrar-se natural, nem no mostrar-se científico-positivo do ente. Como coisa que não se mostra deste modo, ela está encoberta em relação ao ente que se mostra de maneira extra-científica e de maneira científico-positiva. O «não» e o «encoberto» estão em itálico. $\mathrm{O}$ «não» realçado pela impressão em itálico pré-indica que o quid [Was] da Fenomenologia não pode encontrar-se no ente e junto do ente. A ênfase no «estar-encoberto» do quid da Fenomenologia deve chamar a atenção para o estar-encoberto do quid da fenomenologia pertencer a este, não de modo casual mas essencial, e co-constituir o carácter de coisa desta peculiar coisa da Fenomenologia. É porque o estar-encoberto pertence, de forma essencial, ao carácter de coisa desta coisa, que esta tem que ser desvelada a partir desse estar-encoberto, num fazer-ver singular. Somente assim, enquanto desvelada no modo do fazer-ver fenomenológico-mostrativo, ela é fenómeno, algo que-se-mostra-a-respeito-de-si-mesmo. Contudo, a coisa da Fenomenologia encoberta no mostrar-se natural e científico-positivo do ente não se desliga deste. Ao invés, guarda com ele uma relação extraordinária. Enquanto coisa assim encoberta é algo que «essencialmente» pertence ao mostrar-se extra-científico do ente bem como ao científico-positivo. Heidegger anuncia que o modo como a coisa encoberta pertence ao mostrar-se do ente é o de ser «o seu sentido e fundamento». Isto é: o mostrar-se extra-científico do ente, que não requer nenhum pôr à mostra metódico, e o mostrar-se científico-positivo do ente metodicamente determinado fundam-se na coisa encoberta. 
Ora, o que constitui o sentido e fundamento de todo o mostrar-se do ente é dito por Heidegger ao começo do seguinte parágrafo: «O que, contudo, permanece encoberto num sentido excepcional, ou recai de novo na ocultação ou apenas se mostra «dissimulado» não é este ou aquele ente, mas sim, tal como mostraram as precedentes considerações, o ser do ente $\mathrm{e}^{30}$. O sentido e fundamento, em que o ente e o seu mostrar-se se fundam, é o ser do ente. A designação de «sentido» traz-nos à memória a formulação heideggeriana da pergunta fundamental pelo sentido do ser em geral.

Para alcançarmos um entendimento esquemático, que, contudo, permanece forçosamente num plano formal, daquilo que é o ser do ente por contraste com aquilo que é o ente e de como isso constitui o sentido e o fundamento do ente e do seu mostrar-se, concentrar-nos-emos em dois enunciados do $\S 2$ de Ser e Tempo, em que Heidegger oferece uma primeira e orientadora indicação formal do que é o ser quanto àquilo que marca a sua diferença e a sua relação com o ente. Estes enunciados devem servir-nos como fios condutores para a nossa caracterização esquemática do que, na Fenomenologia, deve ser fenómeno, no sentido extraordinário. O primeiro enunciado reza assim: «Aquilo pelo que se pergunta na questão a elaborar é o ser, o que determina o ente enquanto ente, isso em virtude do qual [Woraufhin] o ente, seja ele considerado de que maneira for, está já sempre e de cada vez compreendido.» ${ }^{31}$ Isto significa que ser é, em relação ao ente, aquilo que faz o ente ser um ente e mostrar-se como um ente; enquanto tal, é, porém, simultaneamente isso em virtude do que, de antemão («já sempre, em cada caso» [je schon]) compreendemos o ente quando nos relacionamos com ele no plano extra-científico e da investigação científica.

Todavia, dentro do ser, Heidegger diferencia uma diversidade de modos de ser: a existência, que é o modo de ser mais próprio e extraordinário do ente que nós próprios somos, assim como os modos de ser do ente não-humano, como o estar-à-mão, o estar-perante, a vida e a consistência (este último enquanto modo de ser dos objectos matemáticos $)^{32}$. No quadro do

${ }^{30}$ Ibidem.

${ }^{31}$ Ibidem, 6 (GA 2, 8)

${ }^{32}$ N.T. No original, respectivamente: Existenz, Zuhandensein, Vorhandensein, Leben, Bestand. Estar à mão é próprio do utensílio, de que me sirvo na labuta vital quotidiana. Esse mesmo ente, de que na prática me sirvo, pode ser considerado como objecto de um olhar teorético, que o desloca para a situação de estar-perante um mero observador, alheio às preocupações e conjuntura vitais. A vida é, por outro lado, o modo de ser de todos os seres vivos, para além do ser humano, que tem como carácter mais próprio, excepcional entre os seres vivos, a existência. Mas há também uma certa forma de ser - a que Heidegger não chega nunca a dedicar mais atenção que a de a nomear, pelo que não deixa de levantar dúvidas no momento de encontrar uma expressão para a traduzir - que é o mero "consistir (em)" ou "consistência" (de bestehen aus, Bestand), que caracteriza a esfera objectual da Matemática: aquilo que é no permanente da uma definição (o modo de ser de um triângulo, por exemplo, é a sua consistência em espaço configurado por três ângulos). 
nosso propósito será suficiente se nos circunscrevermos, dentro dos modos de ser do ente não-humano, ao modo de ser do estar-à-mão. Esta designação refere o modo de ser do ente com que lidamos [zu tun haben] quotidianamente nos diferentes domínios do nosso ser-com-os-outros, quer privado quer público. Os modos do lidar com, estar ocupado com, tratar de e todos os outros modos do nosso viver quotidiano constituem aquilo que Heidegger toma terminologicamente como os modos de relacionamento [Verhaltungen] do estar ocupado circunspecto [umsichtiges Besorgen]. O estar-à-mão constitui o modo de ser próprio disso que, num sentido inteiramente amplo, designamos igualmente por utensílios. Ora, se o ser é aquilo que determina o ente enquanto ente, então o ser enquanto estar-à-mão é aquilo que determina o ente enquanto ente à mão, enquanto o que-está-à-mão [Zuhandenes]. $\mathrm{O}$ utensílio à mão é apenas aquilo que ele é com base no sẹu estar-à-mão, em contraste com uma coisa da natureza que está perante nós [vorhandenes Naturding]. Todavia, o estar-à-mão constitui ao mesmo tempo a razão pela qual, no trato activo com o ente à mão, compreendemos antecipadamente este último como o utensílio que, desta ou daquela maneira, está à mão. Para podermos comportar-nos compreendendo os utensílios do nosso mundo circundante [Umwelt] privado e público, temos antecipadamente de haver compreendido o estar-à-mão. Numa palavra: o meu relacionar-me compreendendo com o ente atém-se já a um compreender preliminar do ser deste ente, a partir do qual compreendo, já sempre, em cada caso, o ente ao levar a cabo o meu relacionamento com ele.

Só que ente não é apenas isso com que me relaciono. Eu próprio, que me relaciono com o ente à mão, também sou ente. $\mathrm{O}$ modo de ser que me é próprio é a existência. A indicação formal decisiva respeitante à existência é dada por Heidegger no $\S 4$. Eu, que me relaciono essencialmente com outro ente, não sou nenhum ente que «há no meio de outro ente», mas sim o ente que, «no seu ser, se importa com esse mesmo ser» ${ }^{33}$. O facto de, no meu ser, me importar com o meu ser significa que me relaciono no meu ser com o meu ser. A existência é, enquanto modo de ser, uma relação do ser [Seinsverhältnis $]^{34}$. No meu ser, relaciono-me com o meu ser na medida em que me compreendo no meu ser $^{35}$. A relação do ser característica do meu ser constitui o modo da minha compreensão do ser, o modo em que compreendo o meu próprio ser.

A indicação formal a respeito do ser na sua referência ao ente (cf. § 2 de Ser e Tempo), que até agora explicámos tendo em vista apenas o ente não-humano com o qual me relaciono, abarca também o ser enquanto existência na sua referência ao ente existente. Pois, neste caso, a existência é igualmente aquilo que me determina enquanto o ente que, já sempre, em cada

\footnotetext{
${ }^{33}$ Ibidem, 12 (GA 2, 16)

${ }^{34}$ Ibidem

${ }^{35}$ Ibidem.
} 
caso, sou para mim mesmo, e simultaneamente aquilo em virtude do que eu, já sempre, em cada caso, me compreendi como o ente que eu mesmo sou. No meu relacionamento com o ente à mão relaciono-me sempre também comigo mesmo, embora não da maneira como me relaciono com o que-está-à-mão, e sim da maneira como me mantenho a mim mesmo nos meus modos de relacionamento. Porém para me relacionar comigo mesmo enquanto ente nos meus modos de relacionamento com o ente à mão e, com isso, poder compreender-me a mim mesmo enquanto ente, preciso de passar previamente por um compreender do meu próprio ser enquanto existência. Pois apenas na medida em que, no meu ser, me importo com o meu ser, apenas na medida em que me compreendo no meu ser, posso, enquanto o ente que sou para mim mesmo nos meus modos de relacionamento, relacionar-me comigo mesmo enquanto ente, ou seja, compreender-me enquanto o ente que sou, nos meus modos de relacionamento. Tal como nós, em presença do ente à mão, i.e., do ente não humano, distinguimos entre ele e o seu ser, também o fazemos a nosso respeito. Já respondemos à pergunta acerca da perspectiva sob a qual eu mesmo sou um ente em contraste com o meu ser. Mas necessitamos de a formular expressamente uma vez mais. É sendo que eu sou, para mim mesmo, à maneira dos meus modos de relacionamento com o ente, que eu mesmo não sou. Nestes modos de relacionamento existo corporalmente [leiblich]. Os meus modos de relacionamento ônticos estão constituídos corporalmente, sendo modalidades de eu ter corporalmente trato, lidar com o que-está-à-mão. A corporalidade dos meus modos de relacionamento pertence à maneira como sou um ente existente, em virtude do meu ser enquanto existência.

Em resumo: há que atender a uma duplicação no relacionamento com o ente, bem como no compreender do ser do ente. Relaciono-me sempre com o ente não-humano, e nestes modos de relacionamento, relaciono-me também essencialmente comigo mesmo enquanto ente. $\mathrm{O}$ meu auto-relacionamento ôntico é previamente clarificado e possibilitado pela minha compreensão do próprio ser, enquanto existência, o meu relacionamento ôntico com o ente à mão é previamente clarificado e possibilitado pela minha compreensão do estar-à-mão.

Pertence àquela primeira indicação formal acerca do ser na sua relação com o ente um segundo enunciado: «O ser do ente não «é» ele mesmo um ente» ${ }^{36}$. Isto constitui a primeira indicação formal a respeito da ideia fundamental da diferença ontológica. Entretanto abordámos o ser nas duas modificações do estar-à-mão e da existência. $\mathrm{O}$ enunciado afirma então: o ser, enquanto existência, não é ele mesmo o ente existente; o ser, enquanto estar-à-mão, não é ele mesmo o ente à mão. Embora a existência esteja essencialmente vinculada ao existente, de acordo com o qual determina este enquanto 
tal e em virtude do qual o existente está já sempre, em cada caso, compreendido, enquanto o assim determinante e enquanto aquilo em virtude do que se compreende ela é essencialmente diferente do ente existente. E além disso: ainda que o estar-à-mão esteja essencialmente vinculado ao que está à mão, de acordo com o qual determina este enquanto tal o-que-está-à-mão e, ao mesmo tempo, constitui a razão pela que o-que-está-à-mão está já sempre, em cada caso, desde sempre compreendido, ele [o estar-à-mão] é enquanto o assim determinante e enquanto aquilo em virtude do que se compreende essencialmente diferente do ente à mão.

O ser, tanto o próprio do modo da existência, como o ser do ente não-humano enquanto estar-à-mão, está antecipadamente compreendido para o relacionamento compreensivo com o ente. Ser enquanto existência e ser enquanto estar-à-mão estão abertos [erschlossen], i.e., descerrados [aufgeschlossen] na minha dupla compreensão do ser. Estar-compreendido do ser na compreensão do ser significa Abertura [Erschlossenheit], enquanto estar-descerrado [Aufgeschlossenheit] do ser. A Abertura, enquanto estar-descerrado, é o modo próprio do ser em que o ser é. Se o ser do ente constitui o objecto temático da filosofia fenomenológica, então é-o somente enquanto Abertura do ser. Há, portanto, ser enquanto existência apenas enquanto Abertura da existência; e, do mesmo modo, há o estar-à-mão apenas enquanto Abertura do estar-à-mão.

Qual a relação entre a compreensão (Abertura) do ser próprio, enquanto existência, e a compreensão do estar-à-mão? Pelo facto de a minha existência encerrar em si tanto a compreensão de si mesma como a compreensão do estar-à-mão. Esta dupla compreensão do ser mantém-se numa correspondência de tal modo que no meu ser, enquanto existência, na qualidade da qual me importo, no meu ser, com o meu ser, estou aberto com carácter de mesmidade [selbsthaft], mas de tal modo que nesta Abertura com carácter de mesmidade do meu ser estou distendido [erstreckt] na Abertura do estar-à-mão. Por isso, à Abertura em que se mantém o meu próprio ser enquanto existência chamamos a Abertura distendida e com carácter de mesmidade ou Abertura ex-stática e com carácter de mesmidade; a Abertura do estar-à-mão (e, em geral, do ser do ente não-humano), em que estou distendido na minha Abertura ex-stática e com carácter de mesmidade, é por nós denominada Abertura horizontal. A Abertura ex-stática e com carácter de mesmidade e a Abertura horizontal formam uma unidade e totalidade indestrutíveis. Por isso, falamos igualmente de uma Abertura integral e distinguimos no seu interiot a Abertura ex-stática e com carácter de mesmidade e a Abertura horizontal.

A totalidade desta Abertura com carácter de mesmidade, ex-stático-horizontal do ser constitui, em conformidade com a coisa tratada, aquilo que Heidegger pensa sob a designação de «aí-ser». Sem dúvida, lemos em Ser e Tempo que o ente que nós próprios somos em cada caso é compreendido 
terminologicamente como aí-ser ${ }^{37}$, ao passo que o próprio ser «com o qual o aí-ser pode relacionar-se desta ou daquela maneira e se relaciona sempre de algum modo» é denominado existência ${ }^{38}$. Compreendeu-se muitas vezes esta fixação terminológica no sentido de que aquilo que é tematizado ontológico-existenciariamente enquanto aí-ser, à partida, é apenas o ente existente na sua existência. É certo que Heidegger afirma que com o termo «aí-ser» é designado o ente que existe e com a expressão «existência» o ser deste ente. Contudo, acrescenta que a designação «aí-ser» foi escolhida «enquanto pura expressão do ser» $^{39}$. O ente que eu mesmo sou e que não está perante [vorhanden] ou à mão, como outro ente, mas que existe, recebe a denominação ontológica de «aí-ser», porque, na Abertura ex-stática e com carácter de mesmidade da sua existência, está distendido-aberto na Abertura horizontal dos modos de ser do ente não conforme ao aí-ser. O elemento «ser» no termo «aí-ser» significa ser enquanto existência, ao passo que o elemento «aí» significa a Abertura integral, não apenas, portanto, do ser enquanto existência, mas, juntamente com ela, dos modos de ser de todo o ente não conforme ao aí-ser. A Abertura integral está descerrada de tal modo que na minha Abertura ex-stática e com carácter de mesmidade (existência) estou distendido na Abertura horizontal (ser do ente não conforme ao aí-ser).

Regressemos ao conceito fenomenológico heidegeriano de fenómeno. Se à questão quádrupla sobre o que se há de ter em vista ao desformalizar o conceito formal de fenómeno se deu a resposta que é o ser do ente, encoberto em qualquer mostrar-se do ente, mas que, enquanto assim encoberto, pertence ao mostrar-se do ente enquanto seu sentido e fundamento, então o «ser encoberto» constitui apenas a variante terminológica abreviada para isso que acabámos de apresentar como Abertura integral do ser, que se estrutura internamente de modo horizontal e de modo ex-stático com carácter de mesmidade. No mostrar-se do ente - tanto no natural como no científico-positivo - permanece encoberta e velada a Abertura integral do ser. Se, enquanto Abertura do ser, pretende torná-lo fenómeno, i.e., trazê-lo ao mostrar-se-a-respeito-de-si-mesmo, ele tem de ser expressamente desvelado pelo lógos da Fenomenologia. Uma vez que apenas há ser na sua Abertura, e uma vez que a Abertura dos modos de ser do ente não conforme ao aí-ser está descerrada enquanto horizonte para a Abertura ex-stática e com carácter de mesmidade da minha existência, e uma vez que a Abertura ex-stática e com carácter de mesmidade da minha existência (e dos seu existenciários), numa unidade com a sua Abertura horizontal, constitui o sentido pleno do aí-ser, [por tudo isto] a tematização filosófica do ser do ente e do sentido do ser tem de ser exposta como analítica existenciária do aí-ser. Esta realiza-se como

${ }^{37}$ Ibidem, 7; cf. também 11 (GA 2, 10; cf. 16)

${ }^{38}$ Ibidem, 12 (GA 2, 16)

${ }^{39}$ Ibidem (GA 2, 17) 
desvelamento progresivo da Abertura com carácter de mesmidade, ex-stática e horizontal do ser em geral.

b) A desformalização husserliana do conceito formal de fenómeno na direcção da vida pura ou transcendental da consciência.

Em passagens anteriores das nossas reflexões afirmámos: o que há de comum na compreensão husserliana e heidegeriana de fenomenologia consiste naquilo que Heidegger apresenta como conceito formal de fenomenologia, que coincide no fundamental com o conceito husserliano de evidência tanto quanto este se expressa na máxima «às coisas mesmas». Se partirmos do modo como Heidegger coloca a questão da desformalização do conceito formal de fenómeno num conceito fenomenológico de fenómeno, a diferença relativamente a Husserl surge quando nos confrontamos com o problema de saber o que, segundo Husserl, se há de ter em vista ao desformalizar o conceito formal de fenómeno num conceito fenomenológico. O objecto temático da fenomenologia husserliana é a vida da consciência com as suas vivências ou actos e com aquilo de que se tem consciência nos actos de consciência como referido ao domínio objectual. Se o fenómeno acabado de mencionar há-de sê-lo no sentido fenomenológico, i.e., no sentido filosófico e não apenas vulgar, então tem de ser igualmente algo que não se mostra quer no mostrar-se natural do ente, quer no mostrar-se científico-positivo, nos quais está encoberto e velado; mas que, enquanto assim velado, constitui de algum modo o fundamento para o mostrar-se natural e científico-positivo do ente. Enquanto assim velado requer também, de forma essencialmente necessária, um pôr à mostra e um desvelamento expressos que se diferenciam igualmente de um pôr à mostra científico-positivo.

Mas não será o meu eu, com a sua vida da consciência, com as suas diversas vivências e actos de perceber, lembrar, esperar ou ajuizar, e não serão como os objectos das minhas vivências, aquilo que se me mostra a mim desde sempre e sem um pôr à mostra fenomenológico expresso? Não serei eu próprio quem está dado em cada instante da minha vida vígil de consciência nas diversas vivências da consciência? Não serão os objectos das minhas vivências de consciência que se me mostram desde sempre na minha vida natural de conciência? Pode concordar-se com isto mas, ao mesmo tempo, objectar também que, naquele modo como estou desde sempre manifesto para mim mesmo na minha vida de consciência, este eu não deve tornar-se objecto temático da fenomenologia da consciência. Na introdução ao II volume das Investigações lógicas, Husserl afirma de forma programática: «A fonte de todas as dificuldades reside na orientação antinatural da intuição e do pensamento que é exigida na análise fenomenológica. Em vez de ficarmos absorvidos pela execução dos actos estratificados de diversos modos e, consequentemente, duma forma por assim dizer ingénua, 
determinarmos como sendo os objecto visados no seu sentido [...], devemos antes «reflectir», ou seja, converter em objectos os próprios actos e o seu conteúdo imanente de sentido» ${ }^{40}$. Na execução natural da consciência vivemos nos nossos actos de tal modo que os experienciamos atematicamente, estamos absortos por eles e ficamos direccionados tematicamente apenas para os objectos visados nos actos. A esse percorrer vivencial e desatento desses actos pertence o facto de supormos, ingenuamente, que os objectos dos nossos actos - a que estamos entregues no perceber, no lembrar-se ou no desejar - existem, isto é, estão perante nós independentemente desses actos.

Neste mostrar-se natural de mim mesmo (neste estar-dado-de-si-mesmo [Selbstgegebenheit] natural) e dos objectos das minhas vivências permanece velado algo que apenas pode ser desvelado por intermédio de uma peculiar reflexão. Nesta, retrocedo da minha entrega vital aos actos para os objectos que suponho, ingenuamente, existirem, e inverto a direcção do meu olhar tematizante de maneira objectivante para actos que, de outro modo, permaneceriam sem tematizar. Isso que a reflexão fenomenológica põe à mostra e que agora, por meio da atitude fenomenológica do pensar, se mostra a respeito de si mesmo enquanto o velado da execução ingénua de actos e, consequentemente, se converte em fenómeno, [isso], dizia-se, é a pura essência [Wesen] dos actos e a sua referência essencial aos objectos. Nesta atitude de investigação fenomenológica, os actos da consciência mostram-se na sua essência geral e especial. A sua essência geral encontra-se encerrada na sua intencionalidade. Ela implica que qualquer acto de consciência constitui, essencialmente e não por causa apenas do surgir fortuito de objectos, um referir-se-a-algo. A essência especial dos actos significa que cada tipo de acto se refere ao seu objecto de acordo com a essência própria de cada tipo de acto: o acto percipiente refere-se ao que está presente de modo corpóreo tornando-o actual [gegenwärtigend], o acto de relembrar refere-se ao que é corporeamente presente-sido, presentificando-o.

O descobrimento fenomenológico da intencionalidade como constituição essencial das vivências de consciência encerra a compreensão essencial de que os objectos de vivência não existem assim sem mais, como se supõe na vida ingénua-natural da consciência; ao invés aquilo que eles são, e na qualidade do qual tenho consciência deles, são-no apenas na imanência intencional da consciência: [eles são] imanentes enquanto aquilo sob a forma do qual estão visados nos actos sempre de cada vez em conformidade com a essência de cada tipo de acto. Os objectos de experiência sensíveis só estão presentes intencionalmente na consciência, i.e., só estão percebidos ou lembrados no modo como eles diversamente se apresentam ou aparecem nos actos que os visam. Também Husserl reporta expressamente o termo «fenó- 
meno» ao grego $\phi \alpha$ lvo $\mu \varepsilon v o v$ e traduz este por «o-que-aparece» ${ }^{41}\left[\right.$ Erschei- $^{-}$ nende]; porém, pensa o-que-aparece não como aparição, no sentido em que Heidegger o demarca relativamente ao que-se-mostra, mas justamente no sentido de o que-se-mostra. Em conformidade com a diferença intencional entre acto de consciência e objecto do acto, Husserl distingue entre o que-aparece (enquanto objecto de acto) e o seu aparecer ou modo de aparição nos actos de consciência.

\section{c) Os fenómenos fenomenológicos em Husserl e em Heidegger}

Os fenómenos da fenomenologia de Husserl constituem o todo da minha vida da consciência subjectiva, descerrada na atitude de pensamento fenomenológica e tematizada nas suas vivências constituídas intencionalmente e nos objectos de que se tem consciência intencional. A pergunta decisiva reza agora assim: Qual é a relação entre o que Husserl denomina fenómenos fenomenológicos e os fenómenos fenomenológicos de Heidegger? Qual é a relação entre os fenómenos da consciência e os fenómenos do aí-ser?

De modo a obter um ponto de orientação para uma confrontação comparativa, tem de se dizer, para já, que o que, para Husserl, são os actos e vivências de consciência constituídos intencionalmente, são, para Heidegger, os modos de relacionamento do aí-ser. A tematização fenomenológica husserliana dos actos intencionais é, do ponto de vista do modo como Heidegger coloca a questão, uma análise filosófica dos modos de relacionamento. Esta desvela nos actos aquilo que permanece velado na execução ingénua, pré-filosófica dos actos. Todavia, para Heidegger, os actos, enquanto modos de relacionamento, são aquilo no que estou dado a mim mesmo, enquanto ente com carácter de mesmidade: pré-fenomenologicamente, no modo do percurso vivencial desatento a si mesmo; fenomenologicamente, no modo da tematização desveladora. Porém, a vida nos meus modos de relacionamento intencionais não é, enquanto o estar-dado-de-si-mesmo ôntico, o ser de mim mesmo na diferença ontológica relativamente a mim enquanto ente com carácter de mesmidade. O meu estar-dado-de-si-mesmo ôntico, nos meus modos de relacionamento intencionais, tem por base a Abertura do meu ser enquanto existência, ainda velada para a tematização fenomenológica dos modos de relacionamento. O desvelamento mostrativo da Abertura ex-stática e com carácter de mesmidade da minha existência pertence, por isso, para Heidegger ao tema primeiro da filosofia fenomenológica.

Quando Heidegger qualifica de modo de relacionamento aquilo a que Husserl chama vivência ou acto, não se trata aí apenas de um uso linguístico distinto. $\mathrm{O}$ fundamento para a diferente designação terminológica reside no

${ }^{41}$ E. Husserl, Die Idee der Phänomenologie. Husserliana Bd. II. Ed. de W. Biemel, Den Haag, Nijhoff, $1958^{2}, 14$. 
facto de a interpretação [Auslegung] e determinação deste fenómeno serem principialmente diferentes, ou seja, serem de carácter hermenêutico e não reflexivo. Uma das mais importantes ligações temáticais de Heidegger com Husserl é a sua valorização positiva da compreensão fenomenológica husserliana da intencionalidade. Por isso, os modos de relacionamento do aí-ser, os modos do tratar com e do lidar com, são, para Heidegger, essencialmente modos do referir-se àquilo com que trato e com aquilo em que estou ocupado, e, por essa razão, estão constituídos intencionalmente. A teoria da intencionalidade constitui, para Heidegger, um primeiro e decisivo passo no caminho do afastamento relativamente à teoria da esfera «interior» do sujeito, que tem de ser ultrapassada primeiro para qualquer relação com o mundo. Mas quando efectivamente e, na verdade, de forma hermenêutica, Heidegger põe à mostra este fenómeno, ele não fala apenas do acto de consciência e tão-pouco da intencionalidade do modo de relacionamento. Em vez disso fala do «ser residindo junto dos entes intramundanos» [Sein-beim-innerweltlichen-Seienden]. Se, por esta razão, Heidegger entende o fenómeno, que Husserl determina como acto de consciência intencional, enquanto modo de relacionamento intencional e este como ser residindo junto do ente, então ele retro-radica a intencionalidade do modo de relacionamento, fixando-a na constituição do ser do aí-ser relacional. Sem dúvida, o relacional ser-residindo-junto-do-ente não é ele próprio a constituição do ser. Mas é o modo como o aí-ser, na base da sua própria constituição de ser ex-stática, vai sendo residindo junto do ente com o qual se relaciona enquanto ente relacional.

O ser-residindo-junto-de [Sein-bei] dos modos de relacionamento constitui, em conformuidade com o seu tipo de ser, o estar ocupado. O ser-residindo-junto-do-ente que está ocupado é, em si, um duplo fenómeno: um fenómeno fundado e um fenómeno fundante. Até aqui dirigimos o nosso olhar somente para o fenómeno fundado: o modo de relacionamento ocupado, em que o aí-ser é sendo ele mesmo. O enraizamento da «intencionalidade» do modo de relacionamento ocupado na existência ex-stática constitui a fundamentação do modo de relacionamento ocupado ôntico no ser-residindo-junto-do-ente ocupado ex-stático. Este último forma, enquanto existenciário, juntamente com os existenciários do projecto e do estar-lançado, a totalidade da existência ex-stática, que Heidegger denomina terminologicamente cuidado [Sorge]. Enquanto cuidado, o aí-ser está aberto com carácter de mesmidade e de modo ex-stático nos três ex-stases [Ekstasen] do projecto, do ser-lançado e do ser-residindo-junto-de ex-stático. Conceber a intencionalidade ôntica a partir da constituição de ser ex-stática do aí-ser significa compreendê-la enquanto ser ôntico-ocupado residindo junto do ente ocupado e desvelar o ocupar-se ôntico no seu estar-fundado na Abertura com carácter de mesmidade e ex-stática do ser-residindo-junto-de ex-stático, que forma uma unidade com o projecto ex-stático e o ser-lançado ex-stático. O seu desvelamento constitui o tema primeiro da fenomenologia, porque apenas 
a partir da Abertura ex-stática e com carácter de mesmidade da constituição ex-stática do cuidado pode ser clarificado o referir-se ôntico-intencional ao ente.

A tematização fenomenológica husserliana de como o objecto intencional aparece dum modo diverso nos actos de consciência constitui, duma perspectiva heideggeriana, a análise filosófica do mostrar-se do ente referido a um modo de relacionamento. A maneira do objecto intencional aparecer nos actos de consciência (por ex., os modos de aparição lateral e em perspectiva) constitui o mostrar-se filosoficamente tematizado do ente-mas não [é] o ser do ente que se mostra, que tem de ser pensado a partir da diferença ontológica com o ente. $\mathrm{O}$ aparecer referido ao acto ou ao modo de relacionamento, tanto o natural como o fenomenologicamente tematizado, dá-se sobre a base da Abertura velada do ser que aparece (no que respeita à tematização fenomenológica do aparecer do ente, referido a um modo de relacionamento). $\mathrm{O}$ desvelamento desta Abertura horizontal do ser coincide com o desvelamento da Abertura ex-stática e com carácter de mesmidade da existência (cuidado), constituindo o tema primeiro de uma fenomenologia hermenêutica do aí-ser - em contraste com a fenomenologia reflexiva da consciência.

\section{§ 3. Fenomenologia enquanto método de acesso ao campo de investigação temático (segundo princípio metódico)}

\section{A) Os três encaminhamentos metódicos de Heidegger}

A meditação sobre os conceitos formal e fenomenológico de fenómeno e de Fenomenologia apresentou até aqui o método fenomenológico como um modo de proceder: como um fazer-ver, que expressamente põe à mostra, aquilo que se mostra a respeito de si mesmo e por si mesmo. Só que, com isso, não sabemos ainda que caminho há de tomar o fazer-ver mostrativo, o logos da Fenomenologia, para trazer ao mostrar-se-a-respeito-de-si-mesmo o ser do ente, ou, mais precisamente, a Abertura com carácter de mesmidade, ex-stática e horizontal do ser em geral. A pergunta metódica pelo caminho é a questão de como nos chegamos a dar conta do ser do ente, de tal modo que o possamos tematizar devidamente - ser este que determina o ente enquanto ente, e em virtude do qual desde sempre de cada vez compreendemos o ente no nosso relacionar-nos com ele, mas que enquanto deste modo determinante e enquanto razão do compreender, se vela no mostrar-se do ente.

Também sobre isto diz algo decisivo o parágrafo metodológico em Ser e Tempo, embora somente num único enunciado. Ora, é o curso de Marburgo Os problemas fundamentais da Fenomenologia, publicado na edição da Obra Integral que lança luz sobre a significatividade [Bedeutsamkeit] meto- 
dológica daquele enunciado. Este é precedido primeiramente por um enunciado que, uma vez mais, diz algo fundamental com base na discussão antecedente acerca do modo de proceder: «O modo de ir ao encontro próprio do ser e das estruturas de ser no modo do fenómeno tem de ser obtido primeiro que tudo a partir dos objectos da fenomenologia» ${ }^{42}$. Contudo, lemos a seguir: «Por isso, tanto o ponto de partida da análise como o acesso ao fenómeno e a passagem pelas dissimulações dominantes requerem uma certificação metódica específica» ${ }^{43}$. No mencionado curso de Marburgo, Heidegger discute as três peças fundamentais do método fenomenológico: a redução fenomenológica, a construção fenomenológica e a de-struição fenomenológica $^{44}$. Mostra-se aí que as tarefas de certificação fenomenológica do ponto de partida da análise, do acesso ao fenómeno do ser e da passagem pelas dissimulações dominantes são assumidas, respectivamente, pela redução, construção e de-struição fenomenológicas. Estas três peças fundamentais configuram, sob a forma de três encaminhamentos, aquilo a podemos chamar o segundo princípio metódico. Sabemos, entretanto, que aquilo que Heidegger denomina modo de proceder fenomenológico é, para Husserl, o princípio da evidência formal, no sentido da máxima de investigação fenomenológica, que ele qualifica de primeiro princípio metódico. Afirmámos anteriormente que o falar de um primeiro princípio metódico remete para um segundo. Ora, aquilo que, com Husserl, mas também com Heidegger, podemos designar como segundo princípio metódico, corresponde aos três encaminhamentos metódicos. Husserl, no âmbito da Fenomenologia transcendental, qualifica o seu segundo princípio metódico como método da epoché e redução ${ }^{45}$ fenomenológicas ou transcendentais, a que também dá o nome de método fundamental $^{46}$. Este, enquanto segundo princípio metódico, constitui a transformação transcendental daquela reflexão fenomenológica, na qual saio da execução ingénua de actos e reflicto sobre a própria vida dos actos. Não devemos confundir esta reflexão com a reflexão que constitui, para Husserl, o ter-em-vista fenomenológico no sentido da máxima «às coisas mesmas».

O método fundamental da epoché e redução é, tal como os três encaminhamentos de Heidegger, um método de acesso que cuida de facultar metodicamente o acesso a qualquer campo de investigação da fenomenologia e que, enquanto método de acesso, não se deve confundir com o método do modo de proceder.

\footnotetext{
${ }^{42}$ M. Heidegger, SuZ, 36 (GA 2, 49).

${ }^{43}$ Ibidem

${ }^{44}$ M. Heidegger, Die Grundprobleme der Phänomenologie. GA 24. Ed. de F.-W. von Herrmann, Frankfurt, Klostermann, $1977^{3}, \S 5,26$ ss.

${ }^{45}$ Cf., a este propósito: E. Husserl, Ideen I, 2.: "Die phänomenologische Fundamentalbetrachtung”, 48 ss., especialmente $\S 33,57$ ss. (Husserliana, III, $\S 33,57$ e 69 ss.)

${ }^{46}$ E. Husserl, Cartesianische Meditationen. Husserliana, I, § 8, 61.
} 
Como se vê, tanto Husserl como Heidegger falam, no âmbito do segundo princípio metódico, de uma redução, ainda que sempre com significados fundamentalmente diferentes. Ambos os significados de «redução» se diferenciam tal como reflexão e hermenêutica e, consequentemente, consciência e aí-ser. Comum à redução transcendental de Husserl e à redução hermenêutica heideggeriana é apenas a sua pertença ao método de acesso fenomenológico em contraste com o método do modo de proceder.

Que significa a redução fenomenológica para Heidegger $?^{47}$ Ela é o primeiro encaminhamento em direcção ao ser do ente enquanto o objecto temático da Fenomenologia. Visto que ser é essencialmente ser do ente, a análise fenomenológica tem de partir do ente. Sendo assim, tem de visar o ente, cujo ser deve ser mostrado, de tal modo que ele se mostre enquanto determinado pelo modo de ser que lhe é próprio. Simultaneamente, a análise tem de evitar considerar, para o ponto de partida da análise, o ente num tipo de ser que dissimula o seu modo de ser genuíno. A vigilância crítica, aqui dominante, constitui a tarefa da passagem fenomenológica pelas possíveis dissimulações. Partindo do ente, o olhar fenomenológico executa uma viragem que se afasta do ente temático, em regra considerado único (quer na abordagem natural, quer na da investigação científica), e se volta para o ser (modo de ser) deste ente, de tal modo que, doravante, na atitude filosófica fenomenológica, o ser estará presente ao olhar de forma temática e o ente deste ser somente ainda de forma co-temática. Que a análise fenomenológica do ser do ente tenha de partir do ente da maneira que foi caracterizada, significa que, doravante, também «o conceito vulgar de fenómeno [ente] passa a ser fenomenologicamente relevante ${ }^{48}$. Observe-se que o conceito vulgar de fenómeno passa a ser relevante não, v.g., num plano científico-positivo, mas no fenomenológico, em virtude do desvelamento do ser.

$\mathrm{Na}$ construção fenomenológica, que se segue à redução fenomenológica, o olhar fenomenológico aproxima-se de forma desveladora e compreensivamente captadora do ser apenas visado pela redução ${ }^{49}$. Daí se falar de acesso ou passagem para [Zu-gang] o ser enquanto o que-se-mostra-a-respeito-si-mesmo.

A terceira peça fundamental do método de acesso fenomenológico, a de-struição fenomenológica, enquanto travessia crítica dos fenómenos dissimuladores, não se segue agora à segunda parte da mesma forma que esta se seguiu à primeira. Visto que na de-struição fenomenológica é posta em exercício a função crítica do método de acesso fenomenológico, ela acompanha tanto a actividade de redução, como a da construção. Enquanto travessia fenomenológico-crítica das dissimulações que tapam os genuínos fenómenos de ser, a de-struição fenomenológica não entra em acção, dentro do plano

${ }^{47}$ Cf. M. Heidegger, Die Grundprobleme der Phänomenologie. GA 24, § 5, 28 ss.

${ }^{48}$ M. Heidegger, SuZ, 37 (GA 2, 49 ss.).

${ }^{49}$ M. Heidegger, Die Grundprobleme der Phänomenologie. GA 24, 29 ss. 
sistemático de Ser e Tempo, somente e pela primeira vez na sua II Parte, que tem como tarefa uma de-struição fenomenológica da Historia da Ontologia ${ }^{50}$. Ao invés, já o primeiro passo da analítica fenomenológica que se desenvolve no $§ 12$, e se mantém ainda dentro das fronteiras da redução fenomenológica, tem a acompanhá-lo a travessia crítica pela dissimulação, em que, por enquanto, o ser-em [In-Sein] do aí-ser se mostra ao olhar auto-tematizante.

No caminho da redução e da construção, acompanhadas pela destruição que funciona criticamente, desvela-se progresivamente em Ser e Tempo o ser do ente que eu próprio sempre de cada vez sou, enquanto a Abertura ex-stática e com carácter de mesmidade da minha existência e dos existenciários que a formam. Do mesmo modo, o ser do ente, com o qual me relaciono de cada vez na qualidade de ente existente, desvela-se enquanto Abertura horizontal dos modos de ser do ente não conforme ao aí-ser. No caminho da analítica ontológica-existenciária, a Abertura ex-stática e com carácter de mesmidade desvela-se enquanto Abertura, a cujo sentido existenciário é inerente o estar descerrado e distendido na Abertura horizontal do ser de todo o ente não conforme ao aí-ser.

\section{B) O método fundamental de Husserl}

O que é que, em contrapartida, realiza a redução fenomenológico-transcendental e a epoché fenomenológico-transcendental husserlianas? Epoché significa abstenção [Enthaltung] e é mesmo isso que tem em vista. Segundo Husserl, enquanto fenomenólogo, a prática da epoché dá-se, quando me abstenho reflexivamente do instituir um estar-perante [Vorhandenheitsetzung], que a minha vida de consciência natural desde sempre sustentou, de forma inexplícita. Neste instituir, que determina a minha vida de consciência ingénua e a minha execução de actos ingénua, tomo como estando-perante e, nesse sentido, como sendo efectivamente real toda a realidade do mundo, tanto a física como a própria [realidade] psíquica da minha vida de consciência anímica subjectiva. A este instituir natural e geral do estar-perante, que Husserl qualifica igualmente de tese geral da atitude natural da consciência [Bewusstseiseinstellung], ${ }^{51}$ pertence o perviver desatento dos meus actos de consciência, velador de si mesmo, e o viver exclusivamente direccionado para as coisas da minha vida psíquica experienciadora, activa e científico-positivamente cognoscente, [coisas estas que estão] previamente dadas, que são visadas como existindo independentemente da consciência, e relativamente às quais se dá, neste sentido, como assente que estão perante nós sem mais. 
A epoché fenomenológico-transcendental constitui, enquanto abstenção reflexiva relativamente a esta tese geral natural-ingénua, o voltar-me reflexivo para a vida da consciência, desatendida em virtude de ser vivida regra geral de forma veladora. Se na vida natural da consciência me encontro sobre o terreno natural do ser do estar-perante, que abarca o mundo enquanto objecto e a mim próprio enquanto sujeito, através da execução da epoché abandono reflexivamente este terreno natural do mundo; reflexivamente, tomo posição em mim mesmo, enquanto vida da consciência transcendental depurada do natural instituir do estar-perante. Através da actividade reflexiva da epoché transcendental, o meu olhar fenomenológico é re-conduzido (reduzido) à minha vida da consciência pura, na sua correlação essencial entre os actos de consciência puros constituídos intencionalmente e os objectos intencionais-imanentes dos actos. Esta correlação respeitante à totalidade da vida transcendental da consciência constitui a relação dos modos de aparição conformes ao tipo de acto com os objectos intencionais que aparecem nos modos de aparição.

Para Husserl, o método de acesso da epoché e redução transcendentais realiza o pôr a descoberto desvelador do ser absoluto da consciência pura. Diz-se absoluto este ser, porque comporta, enquanto sentido intencional, o outro tipo de ser, a realidade enquanto o ser do mundo espácio-temporal ${ }^{52}$. Porém, com base na posição hermenêutica de base heideggeriana, o ser absoluto da consciência, descerrado pela redução, não constitui o modo genuíno do ser do «sujeito». Pelo contrário, no acesso redutivo à esfera absoluta do ser, o «sujeito» funda-se em si mesmo enquanto ego-cogito-cogitatum transcendental e fecha-se definitivamente à possibilidade do desvelamento hermenêutico da sua constituição existenciária do ser e da Abertura horizontal, ex-stática e com carácter de mesmidade do ser em geral.

\section{§ 4. Lógos hermenêutico e reflexivo}

A caracterização da pré-concepção da Fenomenologia na secção $\mathrm{C}$ do $\S$ 7 de Ser e Tempo conclui com a determinação da Fenomenologia como Hermenêutica $^{53}$. O que sucede como passo conclusivo tem obviamente de ser entendido de tal modo que obriga a compreender retrospectivamente todos os passos anteriores na determinação do método fenomenológico como sendo passos realizados para a determinação da Fenomenologia Hermenêutica. A nossa apresentação do método fenomenológico de Ser e Tempo orientou-se pela distinção entre o modo de proceder fenomenológico, enquanto primeiro princípio metódico, e o método de acesso fenomenológico, enquanto segundo princípio metódico. Modo de proceder e método de acesso

${ }^{52}$ Cf. Ideen I, § 49, 91 ss., § 50, 53 ss. (Husserliana, III,114 ss., 118 ss.)

${ }^{53}$ M. Heidegger, SuZ, 37 (GA 2, 27 ss, 50). 
têm, por conseguinte, de ser compreendidos como princípios da Hermenêutica. A Hermenêutica, tal como Heidegger a elaborou pela primeira vez e de forma fundamental no curso de $K N S$, demarca-se da reflexão e teoria no sentido explicado. $\mathrm{O}$ modo de proceder hermenêutico e o método de acesso hermenêutico constituem princípios metódicos a-teoréticos e a-reflexivos. Em contrapartida, o modo de proceder e o método de acesso na Fenomenologia husserliana são de natureza teorético-reflexiva. Importa agora, portanto, distinguir o modo de proceder e o método de acesso fenomenológicos de Heidegger, no seu carácter hermenêutico, do modo de proceder e método de acesso fenomenológicos de Husserl no seu carácter reflexivo.

Até agora o lógos da Fenomeno-logia foi determinado nas secções B e $\mathrm{C}$ do $\S 7$ de Ser e Tempo como «fazer-ver mostrativo e identificador». Aquilo que o lógos faz ver mostrando e identificando é o que-se-mostra-a-respeito-de-si-mesmo, o fenómeno. $\mathrm{O}$ fazer ver mostrativo e identificador cumpre o sentido da descrição fenomenológica. No fazer ver mostrativo e identificador Heidegger retoma a intuição fenomenológica. $\mathrm{O}$ fazer-ver intuitivo que põe à mostra e identifica, o lógos da Fenomeno-logia, é realizado ou, como em Husserl, de forma reflexiva, ou, como em Heidegger, de forma hermenêutica. O conceito formal de Fenomenologia apresentado por Heidegger é, enquanto formal, neutro relativamente às possíveis formalizações da Fenomenologia, seja ela reflexiva ou hermenêutica.

Ora, para apresentar o carácter hermenêutico da fenomenologia na secção C do $§ 7$ de Ser e Tempo tomamos primeiro «o sentido metódico da descrição fenomenológica» como «interpretação» ${ }^{54}$. Isto significa que o lógos da Fenomeno-logia se realiza enquanto interpretação, por via do fazer-ver mostrativo e identificador. O fazer-ver mostrativo e identificador, a descrição fenomenológica daquilo que se mostra a respeito de si mesmo e a partir de si mesmo neste fazer-ver, é interpretação.

Contudo, também o fazer-ver reflexivo, o pôr à mostra e a identificação reflexivos, pode compreender-se e qualificar-se como interpretação. Na medida em que o acto reflexivo se refere ao acto antes vivido e agora objectivado, à vivência objectualizada da consciência, ele interpreta-o passo a passo relativamente àquilo que o constitui. A interpretação pode também ser reflexão, no caso daquela ser caracterizada como reflexão. E a reflexão pode também ser tomada como interpretação, uma interpretação que sucede na atitude reflexiva. À essência da reflexão, que é aqui especificamente pensada, pertence o sair do perviver da vivência, o desviar do olhar egóico [Ich-Blick] do objecto vivenciado para o vivenciar deste objecto. Mediante este desviar reflexivo do olhar egóico, a vivência reflectida converte-se no objecto intencional da vivência reflexiva. Entre o acto que reflecte e a vivência objectivada desenvolve-se o distanciamento da consideração reflexiva. A

${ }^{54}$ Ibidem, 37 (GA 2, 50). 
vivência, considerada de forma reflexiva e teoricamente objectivada, encontra-se em frente ao que reflecte teoricamente. Aqui realiza-se a interpretação da vivência da consciência, considerada reflexivamente, a partir do distanciamento reflexivo relativamente à vivência a interpretar.

Quando Heidegger, contudo, determina o sentido metódico da descrição fenomenológica como interpretação, fá-lo já demarcando-o do sentido metódico da descrição fenomenológica enquanto reflexão. De modo a tornar terminologicamente inequívoco este sentido não reflexivo de interpretação, e que é diferente da reflexão, entende-se a interpretação enquanto o $\varepsilon \rho \mu \varepsilon v \varepsilon v \varepsilon ı v$. O sentido metódico do pôr à mostra e da identificação fenomenológicos, i.e., descrição, não é a interpretação reflexiva mas sim a interpretação hermenêtica. O que surge como um pleonasmo constitui na verdade a determinação unívoca da interpretação, que é aqui especificamente pensada: não a reflexiva mas a a-reflexiva, a interpretação enquanto hermenêutica. Contanto que a fenomenologia não seja aqui a fenomenologia da consciência mas do aí-ser, o

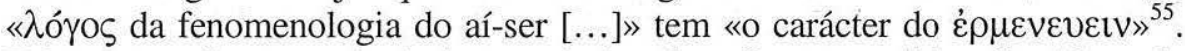
Tal como a fenomenologia hermenêutica da esfera a-teorética da vida e da vivência principia com o compreender interpretativo da vivência do mundo à volta, assim também a fenomenologia hermenêutica do aí-ser pré-teorético começa com o compreender interpretativo dos modos pré-teoréticos de relacionamento com o mundo à volta e com o ente intramundano (utensílio). $\mathrm{O}$ compreender interpretativo não nos enfrenta aos modos de relacionamento, a interpretar como se fossem objectos de reflexão, mas permanece para a interpretação no âmbito da execução do modo de relacionamento que não foi reflexivamente abordado, acompanhando a direcção da sua execução, embora no modo do estar-expresso. Neste modo do estar-expresso, o compreender interpretativo torna expresso o modo de relacionamento enquanto tal e o seu «para quê», de tal forma que o modo de relacionamento se mostra enquanto um «tratar com», e o «com quê» deste tratar se mostra como a situação determinada (significativa) que em cada caso existe. Com isto, fica esboçada a situação hermenêutica de partida para a distinção tanto do modo de ser mais específico dos modos de relacionamento ou modos de tratar, como da constituição primária do ser do ente relativo a uma situação determinada ([do ente] do mundo circundante). Também o pôr à mostra ontológico-hermenêutico do modo de ser e da constituição do ser sucede no acompanhar da direcção da execução dos modos do trato a-teoréticos.

Interpretação enquanto $\dot{\rho} \rho \mu \varepsilon v \varepsilon v \varepsilon \imath v$, enquanto hermenêutica, é determinada sob três aspectos ligados entre si. Mediante o é $\rho \mu \varepsilon v \varepsilon v \varepsilon \imath v$, é «dado a conhecer à compreensão do ser correspondente ao aí-ser mesmo o sentido próprio do ser e as estruturas fundamentais do seu próprio ser» ${ }^{56}$. A fenome- 
nologia hermenêutica do aí-ser constitui a auto-interpretação hermenêutica expressa da compreensão do ser, na sua dimensão universal, correspondente ao aí-ser. A auto-interpretação da compreensão do ser é um dar-a-conhecer-a-si-mesmo. O interpretar hermenêutico (não reflexivo) é um dar-a-conhecer daquilo que a compreensão do ser universal, realizada em conformidade com o aí-ser, encerra de modo inexplícito. Neste dar-se-a-conhecer, a compreensão do ser, realizada inexplicitamente, é elevada progressivamente ao estar-expresso e à transparência expressa. $\mathrm{O}$ importante aqui, porém, é ver que esta auto-interpretação fenomenológica, via dar-se-a-conhecer-a-si-mesmo, não é realizada na postura reflexiva, mas na atitude hermenêutica. Esta atitude hermenêutica tem de ser tomada consciente e com plena transparência. Pois é só a partir desta atitude hermenêutica que Ser e Tempo leva a cabo a série de passos de todas as análises parciais da analítica do aí-ser.

Se o lógos hermenêutico da «fenomenologia do aí-ser» afirma que, por meio dele, é dado a conhecer à compreensão do ser, correspondente ao próprio aí-ser, «o verdadeiro sentido do ser e as estruturas fundamentais do seu próprio ser», então torna-se claro, ao falar do «verdadeiro sentido do ser» em conexão com a «fenomenologia do aí-ser», que esta [fenomenologia do aí-ser] não só inclui - como geralmente se admite - a analítica do aí-ser em sentido restrito (I e II secções da I Parte de Ser e Tempo), como também encerra o pôr a descoberto da temporalitas [Temporalität] horizontal do ser não conforme ao aí-ser (III secção, intitulada «Tempo e Ser»). Isto significa, contudo, que no termo «aí-ser» não apenas se mostra a essência (Ser) do homem, mas também a co-pertença da existência transcendente com o sentido temporal horizontalmente aberto do ser não conforme ao aí-ser. As três secções da I Parte de Ser e Tempo compõem a Ontologia Fundamental. A Ontologia Fundamental no seu todo - portanto, nos três passos da sua análise fundamental e preparatória do pôr-a-descoberto do sentido do ser da existência, que compreende o ser, e da explicação da temporalitas [Temporalität] horizontal do ser não conforme ao aí-ser e correspondente à temporalidade [Zeitlichkeit] existenciária - realiza-se como hermenêutica, como Fenomenologia Hermenêutica.

O que aparece nomeado em primeiro lugar como temática da fenomenologia hermenêutica do aí-ser é a auto-interpretação e o dar-a-conhecer-a-si-mesmo do «verdadeiro sentido do ser», embora isso constitua não o primeiro, mas sim o terceiro passo da hermenêutica. Contudo, o dar-se-a-conhecer-a-si-mesmo do verdadeiro sentido do ser (do ente não conforme ao aí-ser) é mencionado em primeiro lugar, porque o dar-se-a-conhecer-a-si-mesmo, indicado em segundo lugar, o «das estruturas fundamentais do seu próprio ser» está orientado para a resposta à pergunta fundamental pelo sentido do ser em geral, i.e., pela interpretação do sentido temporal do ser do ente não conforme ao aí-ser. «Fenomenologia do aí-ser», em sentido lato, que encerra, sob o título Ser e Tempo, a resposta à pergunta fundamental 
pelo sentido do ser em geral, é «hermenêutica na acepção originária da palavra, pela qual se designava o trabalho da interpretação» ${ }^{57}$. A fenomenologia do aí-ser, no conjunto dos seus três passos, é hermenêutica - e não reflexão. Hermenêutica, porém, significa aqui sempre fenomenologia hermenêutica em contraste com a fenomenologia reflexiva. Fenomenologia do aí-ser é hermenêutica, hermenêutica é fenomenologia do aí-ser. Para a determinação do sentido da hermenêutica, i.e. daquilo que hermenêutica e forma de actuar hermenêutica significam na esfera da fenomenologia do aí-ser, não basta com recorrer à história mais longínqua da hermenêutica e da sua origem. Pois todas as formas da antiga hermenêutica estão determinadas pela hegemonia explícita ou inexplícita do teorético, em relação à qual se diz, no curso de $K N S$, que tem de haver um corte para poder penetrar no reino até agora não descoberto do a-teorético. Ao reino do a-teorético ou pré-teorético pertence, porém, o hermenêutico da fenomenologia do aí-ser. O hermenêutico enquanto método nasce da experiência originária do reino do a-teorético, e, nomeadamente, de tal modo que a noção do a-teorético desenha o traço fundamental da hermenêutica enquanto modo de proceder metódico do a-teorético e enquanto acesso metódico ao a-teorético. O que parece duma forma simples: hermenêutica enquanto trabalho da interpretação constitui, na verdade, uma atitude fundamental metódica que tem, primeiro que tudo, de ser aprendida através do exercício, porque, enquanto método científico, não é nem reflexão nem teoria.

A fenomenologia do aí-ser é ela própria, enquanto hermenêutica, a-teorética e a-reflexiva. A hermenêutica a-teorética e a-reflexiva constitui, contudo, o método científico e, enquanto tal, fenomenológico do reino do aí-ser a-teorético.

Todavia, o logos hermenêutico da fenomenologia do aí-ser é em si tanto um modo de proceder hermenêutico como um modo de acesso hermenêutico. O hermenêutico do modo de proceder fenomenológico significa que o fazer ver mostrativo na atitude não reflexiva constitui o interpretar expresso de o-que-se-mostra-a-respeito-de-si-mesmo. Na situação de partida da fenomenologia hermenêutica do aí-ser, o que-se-mostra-a-respeito-de-si-mesmo são os modos de relacionamento do tratar-com, bem como o com-quê deste tratar e, partindo daqui, o modo de ser do ocupar-se mais específico dos modos de lidar, assim como a constituição de ser do com-quê do tratar, enquanto conjuntura [Bewandtnis] e estar-à-mão. Enquanto modo de proceder fenomenológico, o lógos da fenomenologia do aí-ser é um fazer-ver hermenêutico dos fenómenos, i.e., do que se mostra neste fazer-ver a respeito de si mesmo e a partir de si mesmo.

Enquanto tipo de acesso fenomenológico o lógos da fenomenologia do aí-ser é redução, construção e de-struição hermenêuticas. Enquanto que a 
redução fenomenológica é, para Husserl, de índole reflexiva, para Heidegger ela dá-se de modo hermenêutico. O desvio do olhar fenomenológico do ente intramundano, único que é temático, e que se volta para a constituição de ser deste ente, compreendida atematicamente pela compreensão do ser pré-fenomenológica, realiza-se no acompanhar hermenêutico do modo de relacionamento do tratar com e não numa reflexão sobre o modo de relacionamento. A redução fenomenológica, na qualidade de primeiro encaminhamento para a fenomenologia do aí-ser, constitui o primeiro passo no caminho hermenêutico em direcção à constituição do ser a tematizar do com-quê do tratar. Ela é o primeiro passo para a tematização expressa da constituição do ser. Mas, simultaneamente, a redução hermenêutica é o primeiro passo a caminho do modo de ser a tematizar do modo de relacionamento do tratar. Neste primeiro passo, o modo de relacionamento do tratar executado vividamente torna-se ele mesmo transparente quanto ao modo de ser que o determina. A redução hermenêutica-fenomenológica efectua, na sua realização correlativa, o primeiro passo do tornar expresso aquilo que, pré-fenomenologicamente, é, de facto, compreendido e executado vividamente mas de um modo inexplícito. $\mathrm{O}$ modo explícito e transparente no qual se põe em relevo aquilo que, em regra, é inexplícito e não transparente dum modo temático, são de índole hermenêutica e não reflexiva.

O segundo encaminhamento fenomenológico, dentro da fenomenologia do aí-ser, é a construção fenomenológico-hermenêutica. Ela desvela o que, à partida, a redução hermenêutica visara apenas como desvelável. A construção hermenêutica desvela o ocupar-se como o modo de ser mais específico do modo de relacionamento do tratar, assim como desvela a constituição de ser da conjuntura e do estar-à-mão como a constituição de ser primária do com-quê do tratar. Quando se mostra, no seguimento do caminho da hermenêutica do aí-ser, que o carácter de ser fundamental do ser (Existência) do aí-ser é o do projecto lançado, a construção fenomenológica develadora do ser pode ser entendida como projecto hermenêutico. Pois projectar significa desvelar, abrir, inaugurar. $\mathrm{O}$ pensar da fenomenologia hermenêutica revela-se como projecto hermenêutico em contraste com a reflexão fenomenológica da fenomenologia da consciência. A construção hermenêutica-fenomenológica é o segundo passo no caminho do tornar expresso hermenêutico daquilo que, na execução pré-fenomenológica do aí-ser está compreendido inexplícita, embora vividamente.

Também o terceiro encaminhamento para a fenomenologia do aí-ser, a de-struição fenomenológica, tem essencialmente um carácter hermenêutico e não reflexivo. Enquanto travessia crítica pelos fenómenos dissimuladores, ela acompanha tanto a redução como a construção hermenêuticas. Evita também que seja tido na consideração hermenêutica um modo de relacionamento com o mundo circundante, que se torna fenómeno a partir não do acompanhar da direcção da execução, mas da reflexão sobre esta. Correlati- 
vamente, a de-struição hermenêutica impede que o com-quê do modo de relacionamento com o mundo à volta seja tido em conta como coisa de percepção e não como o que é significativo em termos de mundo à volta. A separação crítica entre fenómenos verdadeiros e dissimuladores, entre fenómeno e aparência dentro da análise fenomenológico-hermenêutica, mantém-se, tal como a redução e a construção, na atitude hemenêutica. A de-struição faz, além disso, a sua distinção atenta no acompanhar hermenêutico dos modos de relacionamento do tratar (Umgangsverhaltungen), e não no reflectir sobre estes.

Todavia, visto que, para Husserl, o método fenomenológico se movimenta essencialmente e apenas em actos da reflexão, o método de acesso fenomenológico, o método fundamental, juntamente com o modo de proceder fenomenológico da evidência, com o princípio de todos os princípios e máxima de investigação "voltar às coisas mesmas», são igualmente, segundo ele, de natureza reflexiva. Epoché e redução fenomenológicas são de índole reflexiva. Enquanto tal, este método de acesso reconduz à vida da consciência pura transcendental, à subjectividade transcendental. Mas quando a redução fenomenológica, em conexão com a construção e a de-struição fenomenológicas, tem um carácter hermenêutico, ela reconduz o olhar hermenêutico fenomenológico ao aí-ser que compreende o ser.

A fenomenologia do aí-ser realiza-se enquanto hermenêutica, e isto agora quer dizer: com redução, construção e de-struição hermenêuticas. Enquanto construção hermenêutica, desvela passo a passo as estruturas fundamentais existenciárias da existência, ou seja, do ser a partir do aí-ser, o aí [Da], a Abertura, não apenas da existência e das suas estruturas existenciárias, mas também o aí dos modos de ser não conformes ao aí-ser e o sentido temporal destes modos de ser. Todo o pôr-a descoberto neste caminho é um pôr à mostra e um identificar e, enquanto tal, um desvelamento hermenêutico (e não reflexivo). O significado primeiro e reitor da hermenêutica é a auto-interpretação da compreensão do ser existente a respeito das estruturas fundamentais do ser do aí-ser e do sentido do ser dos tipos de ser não conformes ao aí-ser. Numa palavra, hermenêutica significa, em primeiro lugar, fenomenologia do aí-ser na sua dimensão de Ontologia Fundamental.

Contudo, o desvelamento hermenêutico das estruturas fundamentais do ser do aí-ser e do sentido temporal do ser dos tipos de ser não conformes ao aí-ser constitui agora o «horizonte [...] para qualquer futura investigação ontológica do ente não conforme ao aí-ser» ${ }^{58}$. Este tipo de investigação seria a tarefa de uma Ontologia Regional, fundada ontologicamente de modo fundamental: uma Metaontologia dos diferentes âmbitos do ente ${ }^{59}$. A Hermenêutica enquanto Fenomenologia do aí-ser (primeiro significado) é ao

\section{${ }^{58}$ Ibidem}

${ }^{59}$ M. Heidegger, Metaphysische Anfangsgründe der Logik im Ausgang von Leibniz. GA 26.

Ed. de K. Held. Frankfurt, Klostermann, 1978, 1990², 199-202. 
mesmo tempo, tendo em vista a sua tarefa de fundamentação ontológica-fundamental, «hermenêutica» no sentido do elaborar das condições de possibilidade de qualquer investigação ontológica» ${ }^{60}$. A hermenêutica no primeiro e fundamental significado é simultanemente «hermenêutica» no segundo significado: o elaborar das condições de possibilidade de qualquer investigação ontológica dos âmbitos do ente.

O terceiro significado de hermenêutica resulta do facto da Hermenêutica, no primeiro sentido mais amplo, se realizar primeiramente «como interpretação do ser do aí-ser» ${ }^{61}$, antes de poder passar ao desvelamento do sentido do ser dos modos de ser não conformes ao aí-ser. À hermenêutica enquanto «interpretação do ser do aí-ser» é-lhe atribuído «um terceiro sentido específico - aquele que, filosoficamente entendido, é o sentido primário de uma analítica do carácter existenciário [Existenzialität] da existência» ${ }^{62}$. O terceiro sentido específico de hermenêutica é o sentido filosoficamente «primário», já que a fenomenologia hermenêutica se afirma como analítica hermenêutica do carácter existenciário da existência (I e II secções da I Parte de Ser e Tempo). A hermenêutica no terceiro, ainda que primário, sentido constitui a primeiro etapa da fenomenologia integral ou hermenêutica do aí-ser, que inclui o desvelamento do sentido do ser temporal dos tipos de ser não conformes ao aí-ser. Com isso realça-se, ao mesmo tempo e uma vez mais, o facto da hermenêutica ou fenomenologia hermenêutica não ser apenas a analítica do aí-ser, no sentido restrito da analítica do carácter existênciário da existência, mas ser também a Ontologia Fundamental na totalidade da sua temática. Além disso a hermenêutica, que significa sempre fenomenologia hermenêutica, é também o método filosófico da ontologia regional ou Meta-ontologia, i.e., das interpretações ontológicas dos âmbitos do ente. A fenomenologia hermenêutica constitui o método da filosofia na totalidade.

Tendo em vista aquilo a que Wilhelm Dilthey chama Hermenêutica, diz-se, finalmente: «Nesta hermenêutica [enquanto analítica do carácter existenciário da existência], na medida em que concebe ontologicamente a historicidade do aí-ser como a condição ôntica da possibilidade da História, está, então, enraízado o que, de maneira apenas derivada pode ser chamado «hermenêutica»: a metodologia das Ciências históricas do Espírito» ${ }^{63}$. A analírica existenciária do modo de ser da historicidade, que significa que o aí-ser vive historicamente a partir das suas possibilidades do ser-no-mundo, constitui o possibilitar ôntico, i.e., conforme ao aí-ser, mas ao mesmo tempo também, o possibilitar ontológico, i.e, conforme ao ser, do desenvolvimento da História e das ciências históricas.

\footnotetext{
${ }^{60}$ M. Heidegger, SuZ, 37 (GA 2, 50).

${ }^{61}$ Ibidem, 38 (GA 2, 50).

${ }^{62} \mathrm{Ibidem}$.

${ }^{63}$ Ibidem, 38 (GA 2, 50 ss.).
} 
No penúltimo período do parágrafo metodológico de Ser e Tempo, Heidegger coloca as subsequentes investigações da fenomenologia hermeneûtica do aí-ser em relação com as investigações husserlianas da fenomenologia reflexiva da consciência: «As investigações seguintes tornaram-se apenas possíveis a partir das bases lançadas por E. Husserl, com cujas Investigações Lógicas a Fenomenologia abriu caminho a si mesma» ${ }^{64}$. As investigações subsequentes de Ser e Tempo são, na verdade, enquanto investigações fenomenológicas, não reflexivas mas hermenêuticas. Elas são investigações hermenêuticas-fenomenológicas não da consciência mas do aí-ser. No entanto, as investigações hermenêuticas apenas se tornaram possíveis a partir das bases lançadas por Husserl, nomeadamente nas Investigações Lógicas, ou seja, das bases lançadas pelas investigações reflexivo-fenomenológicas da consciência. Entre as obras fenomenológicas de Husserl, Heidegger dá primazia à obra que abriu caminho à fenomenologia porque, embora também orientada reflexivamente, ainda não retrocede à auto-certeza do ego-cogito-cogitatum cartesiano, nem retoma ainda o idealismo crítico kantiano. Nas Investigações Lógicas a fenomenologia é ainda levada a cabo em sentido restrito, sem estar sujeita a um determinado ponto de vista. Nas análises das Investigações Lógicas fez-se e faz-se exercitar da forma mais pura o ver e ter-em-vista fenomenológicos. Sem este ver fenomenológico no modo de pensar reflexivo não se teria podido desenvolver o ver fenomenológico na atitude hermenêutica.

Todavia, além do carácter metódico da fenomenologia há também pelo menos uma coisa que pertence à base lançada por Husserl nas Investigações Lógicas: a intencionalidade. No primeiro curso de Marburgo Introdução à investigação fenomenológica (semestre de inverno de 1923/1924), diz Heidegger a este respeito: «Com este descobrimento da intencionalidade fica dado expressamente pela primeira vez em toda a história da filosofia o caminho para uma investigação ontológica radical» ${ }^{65}$. E pouco depois afirma-se: «A fenomenologia dirige a sua atenção justamente não para os actos no seu sentido antigo, mas para um domínio totalmente novo, para o modo do relacionar-se-com, de tal modo que aquilo com que se relaciona o relacionar-se está presente. Enquanto não tiver esta base, não estarei nunca em condições de ver, em que sentido for, na consideração directa do ente algo como um carácter de ser, e, na realidade, de fazer algo como uma ontologia. Por isso volto a dizer que aqui, de facto, está apresentada pela primeira vez na história da filosofia a base para uma investigação ontológica de tal maneira que se pode avançar no modo do investigar científico e não ná forma da mera reflexão» ${ }^{66}$. Apesar da intencionalidade ter sido descoberta como constituição

${ }^{64} \operatorname{Ibidem}(G A 2,51)$.

${ }^{65}$ M. Heidegger, Einführung in die phänomenologische Forschung. GA 17. Ed. de F.-W. von Herrmann. Frankfurt, Klostermann, 1994, 260.

${ }^{66}$ Ibidem, 262. 
essencial da consciência, ela não está ligada apenas à consciência tematizada reflexivamente. Se abdicamos do acesso reflexivo à vida em prol do acesso hermenêutico, a intencionalidade mostra-se igualmente como uma constituição essencial do aí-ser. Aparece aqui, sem dúvida, a compreensão de que a intencionalidade pertence primariamente à vida e ao aí-ser a-teoréticos e, só nessa medida também, à consciência avaliada teoreticamente. A fenomenologia hermenêutica do aí-ser inicia-se, com efeito, ao pôr a descoberto hermeneuticamente na intentio do modo de relacionamento do tratar o modo de ser da ocupação, e no intentum do com-quê do tratar o carácter do ser da conjuntura e do estar-à-mão.

Num olhar retrospectivo sobre os «explicações acerca do conceito preliminar de fenomenologia» ${ }^{67}$ afirma-se que estas haveriam mostrado que o essencial dela [da fenomenologia] não reside em ser efectivamente real [wirklich] enquanto «corrente» filosófica. Acima da realidade efectiva está a possibilidade. A compreensão da fenomenologia reside unicamente no captar-se a si própria enquanto possibilidade». O essencial da fenomenologia enquanto método não reside na realidade efectiva daquela corrente em direcção à qual se desenvolveu a Fenomenologia de Husserl. Ela é «corrente» num duplo sentido. Num primeiro sentido, é uma corrente filosófica na medida em que a Fenomenologia se compreende como reflexão. Num segundo sentido, a Fenomenologia husserliana tornou-se, após as Investigações Lógicas, numa corrente fenomenológica, porque se desenvolveu enquanto filosofia transcendental e idealismo fenomenológico. Ambas as correntes, a reflexão e o idealismo, no seguimento de Descartes, Kant e do Neokantismo (Natorp), são reconhecidas por Heidegger como formando, sem dúvida, a realidade efectiva da fenomenologia, mas nas quais a possibilidade da fenomenologia não se esgota. A fenomenologia, tal como se compreende a si mesma no princípio de todos os princípios e na máxima de investigação, é primariamente «possibilidade». Acima da respectiva realidade efectiva da fenomenologia está a fenomenologia no seu carácter de possibilidade. Compreender a fenomenologia no seu primeiro princípio metódico significa compreendê-la no seu carácter de possibilidade. Compreender a fenomenologia como possibilidade significa ter a experiência de que o voltar às coisas mesmas pode ser igualmente realizado dum outro modo que não aquele que se tornou realmente efectivo. Compreender a fenomenologia enquanto possibilidade pode significar a realização do voltar às coisas mesmas não pelo caminho reflexivo, mas pelo caminho hermenêutico. A fenomenologia enquanto hermenêutica nasce do carácter de possibilidade da fenomenologia. Heidegger compreendeu a filosofia como um filosofar a partir das coisas mesmas no agarrar da Fenomenologia como possibilidade, como a possibilidade da Fenomenologia não reflexiva mas hermenêutica. 
Na nota de rodapé ligada a este passo, diz Heidegger: «Se a investigação subsequente dá alguns passos em frente no abrir [Erschliessung] das «coisas mesmas», o autor agradece isso em primeiro lugar a $E$. Husserl, que familiarizou o autor, durante os anos de aprendizagem passados em Friburgo, com os mais diversos domínios da investigação fenomenológica através duma marcante orientação pessoal e da mais livre cedência de investigações inéditas» ${ }^{68}$. A investigação dá alguns passos «em frente» na medida em que viu e captou [ergriffen], no encontro com a Fenomenologia reflexiva de Husserl, a possibilidade de uma Fenomenologia hermenêutica. A investigação de Ser e Tempo não dá alguns passos «em frente» dentro da fenomenologia reflexiva, mas por intermédio da transfiguração da Fenomenologia reflexiva na Fenomenologia hermenêutica. Contudo, também a hermenêutica continua a ser, enquanto fenomenologia, um abrir das «coisas mesmas». Enquanto fenomenologia ela apoia-se no princípio fundamental do voltar às coisas mesmas, só que esse voltar já não é mais de natureza reflexiva, e sim hermenêutica.

Mas, também estes passos «em frente», dados, a saber, fora da fenomenologia reflexiva enquanto fenomenologia hermenêutica do aí-ser, devem-se à «orientação pessoal marcante» de Husserl e ao estudo das inéditas investigações fenomenológicas de Husserl. Significa isto que: o intensivo e abrangente encontro com as análises fenomenológicas da fenomenologia reflexiva husserliana conduz a uma abordagem ponto de partida e a uma realização seguras da Fenomenologia hermenêutica. Contudo, isto significa, para quem pretenda introduzir-se temática e metodicamente na Fenomenologia hermenêutica do aí-ser, que não pode negligenciar o estudo da Fenomenologia reflexiva de Husserl. Caso contrário, falhar-se-ia o sentido metódico da fenomenologia hermenêutica, que se obtém do encontro com o sentido metódico da fenomenologia reflexiva.

O rigor das análises fenomenológicas husserlianas e o seu ganho de conhecimento filosófico é digno de admiração. A nossa exposição do método da fenomenologia hermenêutica pretendeu, ao mesmo tempo, mostrar que também nela vigora um rigor científico que não fica atrás daquele que existe na fenomenologia reflexiva. As análises hermenêuticas-fenomenológicas de Heidegger em Ser e Tempo manifestam um rigor capaz de medir-se com o rigor metódico das análises reflexivas-fenomenológicas de Husserl nas Investigações Lógicas. E é também por este mesmo rigor metódico no seguimento do modo de proceder e do modo de acesso hermenêuticos que se tem de esforçar o comentador e intérprete na sua acção de re-interpretar e co-interpretar. 